\title{
Hydrothermal processing, as an alternative for upgrading agriculture residues and marine biomass according to the biorefinery concept: A review
}

\author{
Héctor A. Ruiz*, Rosa M. Rodríguez-Jasso, Bruno D. Fernandes, António A. Vicente, José A. Teixeira \\ IBB-Institute for Biotechnology and Bioengineering, Centre of Biological Engineering, University of Minho, Campus de Gualtar, 4710-057 Braga, Portugal
}

\section{A R T I C L E I N F O}

\section{Article history:}

Received 5 August 2011

Received in revised form

22 November 2012

Accepted 26 November 2012

Available online 22 January 2013

Keywords:

Biorefinery

Autohydrolysis

Lignocellulosic material

Macroalgae

Microalgae

Biofuels

\begin{abstract}
A B S T R A C T
The concept of a biorefinery that integrates processes and technologies for biomass conversion demands efficient utilization of all components. Hydrothermal processing is a potential clean technology to convert raw materials such as lignocellulosic materials and aquatic biomass into bioenergy and high added-value chemicals. In this technology, water at high temperatures and pressures is applied for hydrolysis, extraction and structural modification of materials. This review is focused on providing an updated overview on the fundamentals, modelling, separation and applications of the main components of lignocellulosic materials and conversion of aquatic biomass (macro- and micro- algae) into value-added products.
\end{abstract}

(c) 2012 Elsevier Ltd. All rights reserved.

\section{Contents}

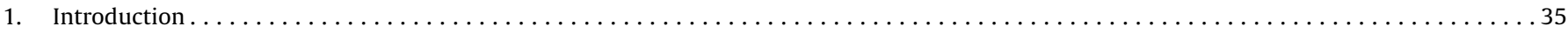

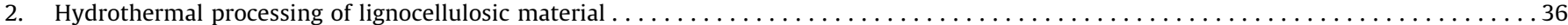

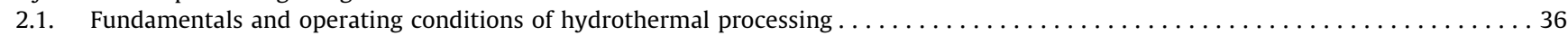

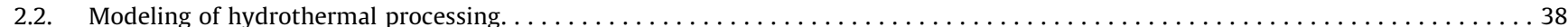

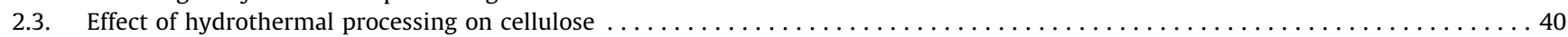

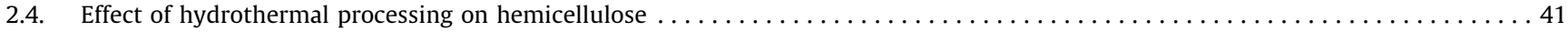

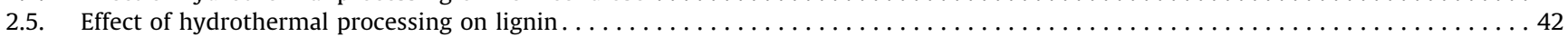

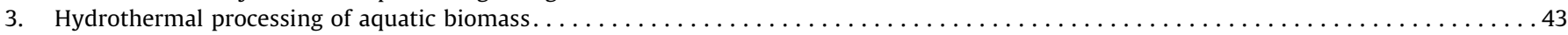

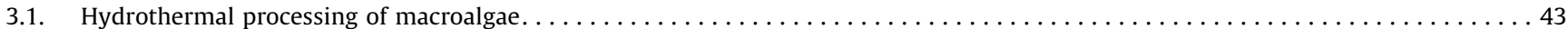

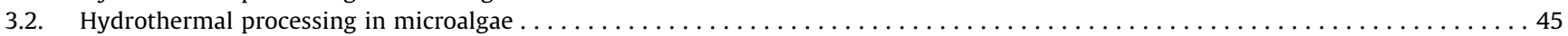

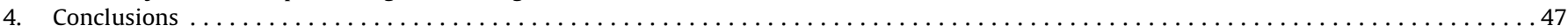

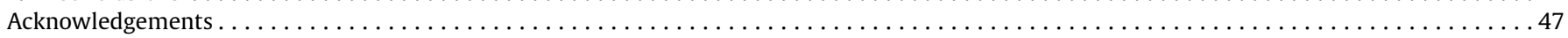

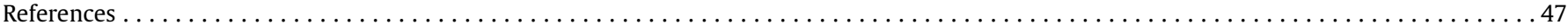

\section{Introduction}

Considering the amount of biomass available, there is a clear opportunity to develop commercial processes that could generate products needed at very high volumes and low selling price. Most of

\footnotetext{
* Corresponding author. Tel.: +351253604 400; fax: +351253604 429 .

E-mail addresses: hector_ruiz@deb.uminho.pt, domitilah@hotmail.com (H.A. Ruiz).
}

such products are now being made from non-renewable resources, mainly through oil refineries. These refineries, starting from a complex mixture (petroleum), use a wide range of unit operations to generate an impressive variety of products that are sold directly or transformed into value-added products such plastics and fibers. Approximately $17 \%$ of the volume of products derived from petroleum in the US is classified as chemicals [1]. If these chemicals could be obtained from renewable resources (e.g., biomass in a biorefinery), it would reduce petroleum dependence while also having a positive environmental impact. In recent years the use of different renewable 
raw materials (lignocellulose material (LCMs) and aquatic marine materials) has been a growing trend for different applications and products such as energy, fuels, chemical, cosmetics, medical applications, construction materials and high added-value products for food or feed. The term "biorefinery" borrows its origin from the classical petroleum refinery concept and refers to biomass conversion into fuels and chemicals with high added-value through the integration of clean processes $[2,3]$. Several technologies have been developed during the last decades that allow this conversion process to occur, the clear objective being now to make this process cost-competitive in today's markets. Hydrothermal processing is an alternative for the fractionation of these raw materials (LCMs and aquatic biomass). The fractionation refers to the conversion into its main constituent: LCMs (i.e., cellulose, hemicellulose and lignin); macroalgae (different polysaccharides depending of taxonomic groups); microalgae (oils, proteins, carbohydrates) [4-6]. Bobleter et al. [7] pioneered in using water for pretreatment to enhance the susceptibility of lignocellulosic material to enzymatic hydrolysis. The processes with liquid water under high temperature and pressure are also called autohydrolysis, hydrothermal treatment, hot compressed water (HCW), hydrothermolysis, liquid hot water (LHW), aquasolve process, aqueous processing and pressure-cooking in water [8-24]. The objective of this review is to present research progresses in hydrothermal processing of lignocellulosic materials and aquatic biomass for the fractionation of their main components. The fundamentals, mathematical modeling, effects of hydrothermal processing on cellulose, hemicellulose and lignin and their applications are reviewed. Additional information on the application of this technology to aquatic biomass (macro- and micro- algae) is also provided.

\section{Hydrothermal processing of lignocellulosic material}

Hydrothermal processing has been considered a cost-effective pretreatment [25] and in general, the major advantages that this process offers are: (1) the process does not require the addition and recovery of chemicals different from water, (2) limited equipment corrosion problems, (3) simple and economical operation [26-29]. For that reason, the hydrothermal processing can be considered an environmentally friendly fractionation process [30]. Lignocellulosic materials (LCMs) are the most abundant renewable biomass and its annual production was approximately estimated in 200 billion metric tons worldwide in 2007 [31]. LCMs are mainly composed of cellulose, hemicellulose and lignin and have great potential as cheap and renewable feedstock for different applications. In general, LCMs include agricultural residues, herbaceous, hardwood, softwood, cellulose wastes and industry co-products. Table 1 shows the composition of different lignocellulose materials. The fractionation of LCMs into products derived from their structural components is an attractive possibility leading to the biorefinery concept. However, the main problem of fractionation is the recalcitrant nature of these materials. Fractionation may be achieved through hydrothermal processing, whose first step is hemicellulose solubilization. Fig. 1 shows the scheme of a biorefinery using hydrothermal processing. This process has been mainly used as a pretreatment for bioethanol production; in recent researches, the use of a sequential process has been applied as an alternative of papermaking production, also as a technology for converting agro-food by-products into useful food ingredients [12, 65-71].

\subsection{Fundamentals and operating conditions of hydrothermal processing}

In hydrothermal processing LCMs are exposed to water in the liquid state, at elevated temperature and pressures, that penetrated cell's structures, hydrates cellulose, depolymerizes hemicellulose (to oligomers and monomers) being between $40 \%$ and $60 \%$ of the total biomass dissolved in the process (Fig. 2). In water at high temperatures $\left(150-230{ }^{\circ} \mathrm{C}\right)$, the H-bonding starts weakening, allowing

Table 1

Composition of selected lignocellulosic materials (\% dry matter)

\begin{tabular}{|c|c|c|c|c|}
\hline Raw material & Cellulose (\%) & Hemicellulose (\%) & Lignin $(\%)$ & References \\
\hline \multicolumn{5}{|l|}{ Agricultural residues } \\
\hline Corn cobs & $38.8-44$ & $33-36.4$ & $13.1-18$ & Liu et al. [32]; Wang et al. [33] \\
\hline Corn stover & $34.32-36.5$ & $20.11-31.3$ & $11.9-13.55$ & Weiss et al. [34]; Liu and Cheng [35] \\
\hline Wheat straw & $33-40$ & $20-33.8$ & $15-26.8$ & Ruiz et al. [12]; Talebnia et al. [36] \\
\hline Rice straw & $35-36.6$ & $16.1-22$ & $12-14.9$ & Hsu et al. [37]; Yadav et al. [38] \\
\hline Sugar cane bagasse & $34.1-49$ & $15.79-29.6$ & $19.4-27.2$ & Mesa et al. [39]; Maeda et al. [40] \\
\hline Barley straw & 37.5 & $25.1-37.1$ & $15.8-16.9$ & Sun et al. [41]; García-Aparicio et al. [42] \\
\hline Rice husk & 33.43 & 20.99 & 18.25 & Garrote et al [43]; Abbas and Ansumali [44] \\
\hline Rye straw & $41.1-42.1$ & $23.8-24.4$ & $19.5-22.9$ & Ingram et al. [21]; Gullón et al. [45] \\
\hline Rapessed straw & $36.59-37$ & $19.6-24.22$ & $15.55-18$ & Díaz et al. [13]; Lu et al. [46] \\
\hline Sunflower stalks & 33.8 & $20.2-24.27$ & $14.6-19.9$ & Ruiz et al. [47]; Caparrós et al. [48] \\
\hline Sweet sorghum bagasse & $41.33-45.3$ & $22.01-26.3$ & $15.2-16.47$ & Zhang et al. [49]; Goshadrou et al. [50] \\
\hline \multicolumn{5}{|l|}{ Herbaceous } \\
\hline Switchgrass & $41.2-32.97$ & $25.95-31.1$ & $17.34-19.1$ & Keshwani and Cheng [51]; Hu et al. [52] \\
\hline Alfalfa stems & 24.7 & 14.7 & 14.9 & $\mathrm{Ai}$ and Tschirner [53] \\
\hline Coastal Bermuda grass & 25.59 & 19.29 & 19.33 & Wang et al. [54] \\
\hline \multicolumn{5}{|l|}{ Hardwood } \\
\hline Aspen & 43.8 & 18 & 20.8 & Tian et al. [55] \\
\hline Hybrid Poplar & 48.95 & 21.73 & 23.25 & Pan et al. [56] \\
\hline Eucalyptus & 44.6 & 21.4 & 30.1 & Gonzalez et al. [57] \\
\hline Eucalyptus globulus & 44.4 & 21.8 & 27.7 & Romaní et al. [9] \\
\hline \multicolumn{5}{|l|}{ Softwood } \\
\hline Pinus radiata & 45.3 & 22.5 & 26.8 & Araque et al. [58] \\
\hline Spruce & 43.8 & 20.8 & 28.83 & Shafiei et al. [59] \\
\hline \multicolumn{5}{|l|}{ Cellulose wastes } \\
\hline Newspapers & 60.3 & 16.4 & 12.4 & Lee et al. [60] \\
\hline Recycled paper sludge & 60.8 & 14.2 & 8.4 & Peng and Chen [61] \\
\hline \multicolumn{5}{|l|}{ Industry co-products } \\
\hline Distiller's grains & 12.63 & 16.9 & - & Kim et al. [62] \\
\hline Brewer's spent grain & $18.8-20.97$ & $15.18-32.8$ & $21.7-25.62$ & Carvalheiro et al. [63]; Pires et al. [64] \\
\hline
\end{tabular}




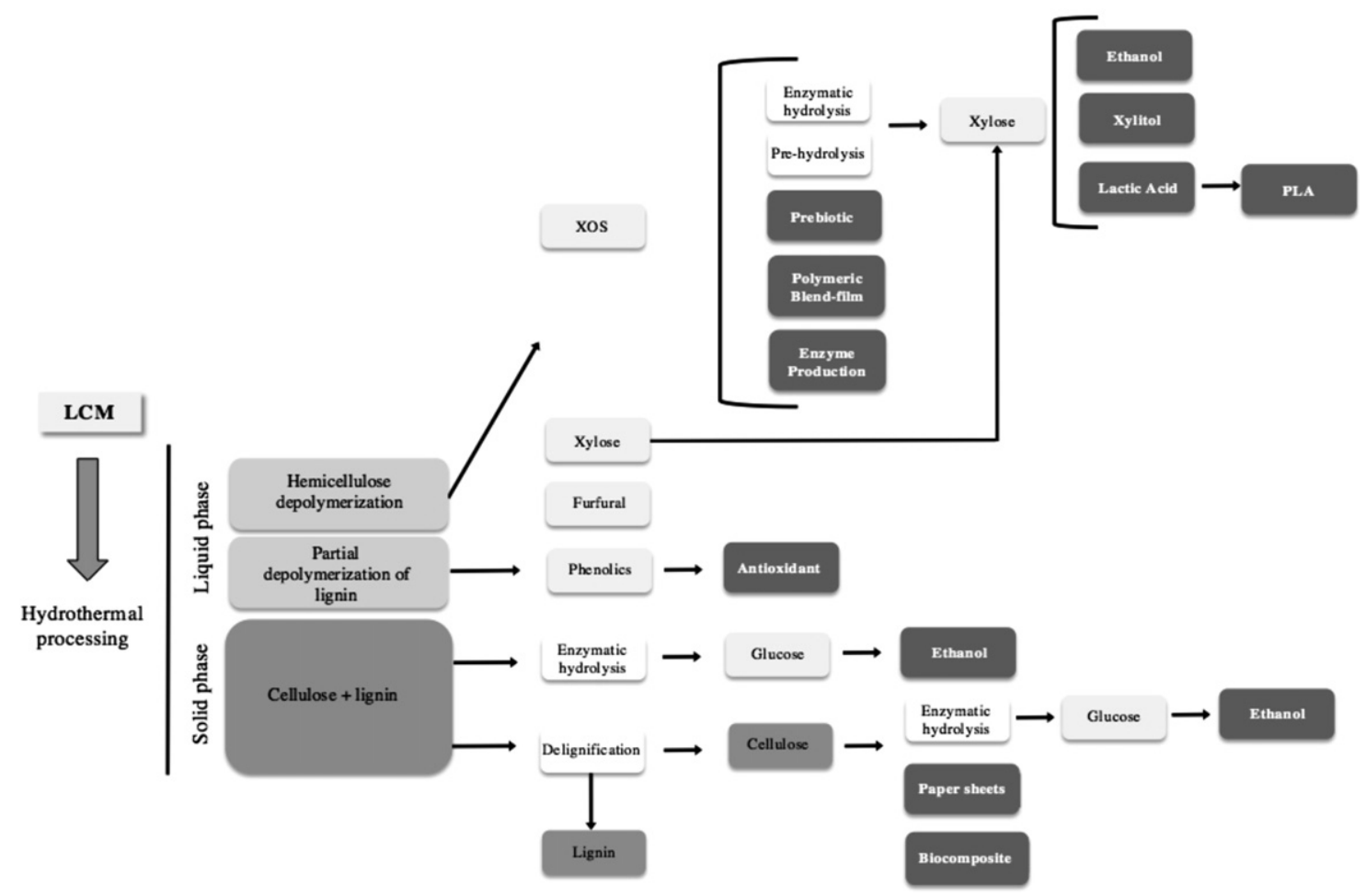

Fig. 1. Scheme of a biorefinery using hydrothermal processing and LCMs as raw material.

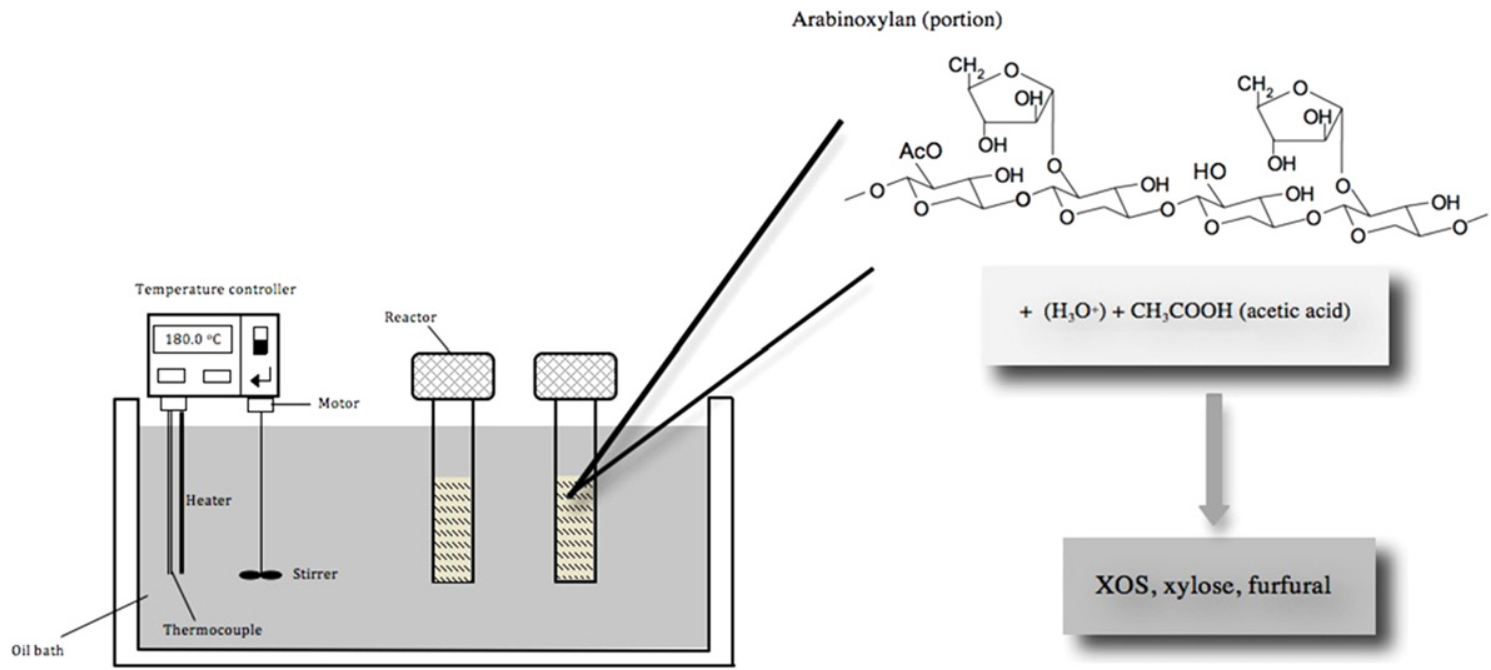

Fig. 2. Batch reactor systems for hemicellulose depolymerization in hydrothermal processing.

autoionization of water into acidic hydronium ions $\left(\mathrm{H}_{3} \mathrm{O}^{+}\right)$that act as catalysts and basic hydroxide ions $\left(\mathrm{OH}^{-}\right)$. In the subcritical region $\left(100-374{ }^{\circ} \mathrm{C}\right)$ the ionization constant $\left(K_{w}\right)$ of water increases with temperature. However, when exceeding its critical point $\left(374{ }^{\circ} \mathrm{C}\right.$ and 22.1 MPa), the values of dielectric constant, ionization constant $\left(K_{w}\right)$ and ionic product of water drop drastically. Moreover, hydronium ions are generated from organic acids, mainly acetic acid from acetyl groups and uronic acid [28,72-75]. Acetyl groups are present in LCMs and as they are associated with hemicellulose, the hydration of the acetyl groups leads to the acidification of the liquor and thus, formation of hydrogen ions. A number of hypotheses have been suggested to explain this phenomenon. According to these considerations, in a recent work, Liu [76] presented the following model for hemicellulose solubilization in hydrothermal processing.

$\mathrm{H}_{2} \mathrm{O} \leftrightarrow \mathrm{H}^{+}+\mathrm{OH}^{-}$

$\mathrm{H}^{+}+\mathrm{H}_{2} \mathrm{O} \leftrightarrow \mathrm{H}_{3} \mathrm{O}^{+}$

$R-\mathrm{PO} A_{C}+\mathrm{H}^{+} \leftrightarrow R-\mathrm{POA}_{C} * \mathrm{H}^{+}$

$R-\mathrm{PO}_{C} * \mathrm{H}^{+}+\mathrm{H}_{2} \mathrm{O} \leftrightarrow R-\mathrm{POH} * H^{+}+\mathrm{HO}_{C}$

$R-\mathrm{PO}_{C} * \mathrm{H}^{+}+\mathrm{H}_{2} \mathrm{O} \leftrightarrow R-\mathrm{OH} * \mathrm{H}^{+}+\mathrm{HPO}_{C}$

$\mathrm{HO}_{C} \leftrightarrow \mathrm{H}^{+}+\mathrm{O} A_{C}^{-}$ 
$R-\mathrm{POH} * \mathrm{H}^{+} \leftrightarrow \mathrm{R}-\mathrm{POH}+\mathrm{H}^{+}$

$R-\mathrm{OH} * \mathrm{H}^{+} \leftrightarrow R-\mathrm{OH}+\mathrm{H}^{+}$

Reaction steps to solubilize hemicellulose

$R-X_{n} \mathrm{OH}+\mathrm{H}^{+} \leftrightarrow R-X_{n} \mathrm{OH} * \mathrm{H}^{+}$

$R-X_{n} \mathrm{OH} * \mathrm{H}^{+}+\mathrm{H}_{2} \mathrm{O} \leftrightarrow R-X_{m} \mathrm{OH} * \mathrm{H}^{+}+\mathrm{H} X_{S} \mathrm{OH}$

Reaction steps to reduce the chain length inside the hydrothermal process liquor

$\mathrm{H} X_{n} \mathrm{OH}+\mathrm{H}^{+} \leftrightarrow \mathrm{H} X_{n} \mathrm{OH} * \mathrm{H}^{+}$

$\mathrm{H} X_{n} \mathrm{OH} * \mathrm{H}^{+}+\mathrm{H}_{2} \mathrm{O} \leftrightarrow \mathrm{HX}_{m} \mathrm{OH} * \mathrm{H}^{+}+\mathrm{HX}_{S} \mathrm{OH}$

where $X_{n}$ represents an $n$-xylooligomer middle group, $m+s=n$, $R$ - denotes the cellulose or lignin bonded to LCMs, $P$ represents a segment of hemicellulose, $\mathrm{HX} X_{n} \mathrm{OH}$ is an $n$-xylooligomer, $\mathrm{HO}_{C}$ represents the acetic acid molecule and $A_{C}$ is $\mathrm{CH}_{3} \mathrm{CO}$ [76]. On the other hand, the most important operational variables of hydrothermal processing include temperature, residence time, particle size, moisture content (ratio liquid/solid) and $\mathrm{pH}$ influence on the fractionation of LCMs and must be taken into consideration to maximize the product yield (i.e., hemicellulose sugar production, accessible surface area for enzymatic saccharification, etc.). The relationship between temperature-time strongly influences the physical-chemical characteristics of LCMs in hydrothermal processing. Ballesteros et al. [77] reported an increase of hemicellulose-sugar degradation at higher temperatures and residence times, concluding that at more severe operational conditions there are more losses of hemicellulosic sugar. For this reason, a strict control is required for high temperature reactions due to thermal degradation. Several works showed that the products (pentose and oil yield) from hydrothermal processing are favored at lower reaction temperatures and longer residence times [78-80]. Normally, when larger particle sizes are used, heat transfer problems lead to overcooking of the exterior (with consequent formation of inhibitors) and incomplete autohydrolysis of the interior. This problem can be overcome by reducing particle size as the first pretreatment step. This size reduction process not only changes the particle size and shape, but also increases bulk density, improves flow properties, increases porosity, increases surface area and is usually required to make material handling easier before hydrothermal processing. The higher surface area increases the number of contact points for chemical reaction [12,81]. Mosier et al. [82] reported that size reduction is not needed since the lignocellulose particles break apart when cooked in water. Ballesteros et al. [83] showed that the utilization of very small chips of softwood in hydrothermal processing would not be desirable to optimize the effectiveness of the process and improve economy, due to the significant energy requirements of particle reduction process. However, in recent work, Hosseini and Shah [84] reported that it is possible to improve in $50 \%$ the energy efficiency of pretreatment by the optimization of particle size properties. According to Ruiz et al. [12], the use of blends with different particle size distributions has a selective influence over the sugar extraction: thus, the use of a blend with defined percentages of the various particle sizes is recommended before carrying out a hydrothermal processing. Moisture content and ratio liquid/solid may also greatly influence the ability of heat and chemicals $\left(\mathrm{H}_{3} \mathrm{O}^{+}\right)$to penetrate LCMs, causing an uneven treatment of material. An uneven treatment can potentially result in the selective degradation of the outer portion of the LCMs, while at the same time the interior is less affected by the treatment [81]. Cullis et al. [85] reported that the moisture content has a dramatic effect on the efficacy of the hydrothermal processing as a substantial decrease in the amount of hemicellulose-derived carbohydrates recovered in the watersoluble fraction was observed when increasing the starting moisture content from 12 to $30 \%$, Rodríguez et al. [86] showed that it is possible to obtain high glucose, xylose, arabinose and acetic acid concentrations by combining high temperatures with a medium-low treatment time and liquid/solid ratio. On the other hand, the formation of hydronium ions from water and from organic acids is an important factor during hydrothermal processing, since the LCMs and water mixture will reach high temperatures and pressures during the process. These high temperatures and pressures will accelerate the acid-catalyzed hydrolysis of cellulose and hemicellulose as well as the acid-catalyzed degradation of glucose and xylose. Monitoring and control of the $\mathrm{pH}$ in hydrothermal processing will maximize the solubilization of the hemicellulose fraction as liquid soluble oligosaccharides while minimizing hydronium ions concentration and, more importantly, the degradation of these oligosaccharides and monosaccharides to degradation products [29,87]. Mosier et al. [88] pretreated corn fiber using $\mathrm{pH}$ controlled liquid hot water at $160{ }^{\circ} \mathrm{C}$ and a pH value above 4.0 and found that $50 \%$ of the fiber was dissolved in $20 \mathrm{~min}$. The carbohydrates dissolved by the pretreatment were $80 \%$ soluble oligosaccharides and $20 \%$ monosaccharides with $<1 \%$ of the carbohydrates lost to degradation products. Cara et al. [89] reported a slight $\mathrm{pH}$ decrease of hydrothermal processing hydrolyzates, in the range of 3.8 to 3.3, and an increase of degradation product concentrations (furfural) from 0.4 to $1.7 \mathrm{~g} / \mathrm{L}$, respectively.

In hydrothermal processing there are different types of reactor configurations. (1) Batch reactor: LCMs solid particles are mixed with water in the reactor (Fig. 3A). The residence time of the reacting solid is long $[8,16,90-92]$. In a recent work, Gullón et al. [45] reported a conversion of $69.2 \%$ from initial xylan into xylooligosaccharides using a batch reactor configuration at $208{ }^{\circ} \mathrm{C}$ and rye straw as raw material; (2) Semi-continuous reactor of (flow-through partial flow-through): hot water is passed over a stationary bed of LCMs and dissolves lignocellulose components while the liquid products are rapidly swept out (Fig. 3B). The residence time of liquid products is short, compared to a batch reactor [16,82,93-98]. Liu and Wyman [99] reported that in this type of reactors the fluid velocity in flow through has a significant impact on hydrothermal processing. Increasing fluid velocity significantly accelerated solubilization of total mass, hemicellulose and lignin even at the similar liquid residence times; (3) Continuous reactor (co-current, counter-current): the LCMs are passed in one direction while water is passed in the same or opposite direction (Fig. 3C and D). A continuous reactor system is also typically required to operate at high temperatures and pressures to achieve a high conversion of the feedstock within a short residence time [16,82,100-102]. Makishima et al. [103] reported a $82 \%$ conversion of xylan in xylose and xylooligosaccharides using a continuous flow type reactor. $\mathrm{Yu}$ and $\mathrm{Wu}$ [16] suggested that the characteristics of liquid products are strongly influenced by the reactor configuration.

\subsection{Modeling of hydrothermal processing}

Modeling in hydrothermal processing provides a way to compare results from experiments carried out at different conditions. Table 2 shows the main mathematical models used in both isothermal or non-isothermal hydrothermal processing (Fig. 4A and B) $[69,104]$. An often used option to modeling the effects of the main operational variables by pseudo first order kinetics is the severity factor $\left(R_{0}\right)$ proposed by Overend and Chornet [105] and Chornet and Overend [106]. This empirical model has been 
A

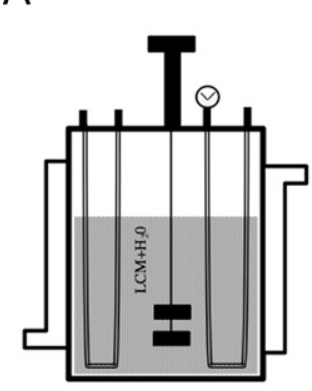

B

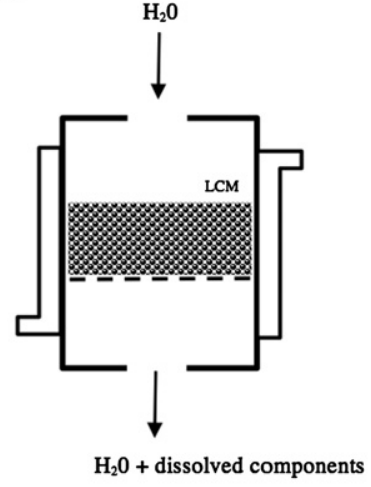

$\mathrm{C}_{\mathrm{H}_{2} \mathrm{O}}$

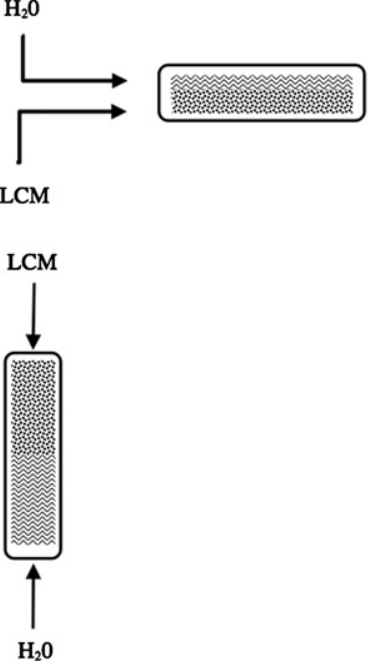

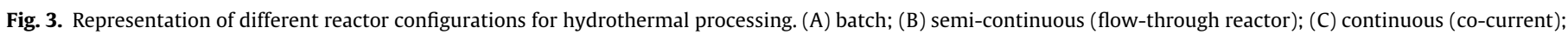
(D) continuous (counter-current)(adapted from Mosier et al. [82]; Yu and Wu [16]).

Table 2

Models used in hydrothermal processing.

\begin{tabular}{|c|c|c|c|}
\hline Effect & Model & Variables & Reference \\
\hline $\begin{array}{l}\text { Severity factor } R_{0} \text {, easy way for comparing } \\
\text { results among experiments carried out under } \\
\text { different conditions of temperature and time. }\end{array}$ & $R_{0}=\int_{0}^{t} \exp \left[\frac{T-100}{14.75}\right] d t$ & $\begin{array}{l}t \text { is the reaction time ( } \min ), T \text { is temperature }\left({ }^{\circ} \mathrm{C}\right) \text {, } \\
100 \text { is the temperature of reference and } 14.74 \text { is } \\
\text { an empirical parameter related with activation } \\
\text { energy, assuming pseudo first order kinetics. The } \\
\text { results are usually represented as a function of log } \\
\left(R_{0}\right) \text {. }\end{array}$ & $\begin{array}{l}\text { Overend and } \\
\text { Chornet [105]; } \\
\text { Chornet and } \\
\text { Overend [106] }\end{array}$ \\
\hline $\begin{array}{l}\text { H-factor }(H F) \text {, is a relationship between time and } \\
\text { temperature, which is only an approximation } \\
\text { of the reaction due to the fact that the proton } \\
\text { concentration changes with time and }\end{array}$ & $H F=\int_{0}^{t} \exp \left(43.186-\frac{16115 K}{T}\right) d t$ & $\begin{array}{l}t \text { is the time }(\mathrm{min}), T \text { is the temperature in }\left({ }^{\circ} \mathrm{C}\right) \text { and } \\
\text { the constants are related with the activation } \\
\text { energy. }\end{array}$ & Liu et al. [76] \\
\hline
\end{tabular}

activation energy. The concept of $H F$ was

development for Kraft/chemical pulping.

However, also has been applied for

hydrothermal processing Griebl et al. [64].

Severity factor $R_{0}$, in a non-isothermal hydrothermal processing, which includes the combination of temperature and reaction time along heating and cooling.

$$
\begin{aligned}
& \log R_{0}=\log \left[R_{0} \text { Heating }+R_{0} \text { Cooling }\right] \\
& \log R_{0}=\left[\int_{0}^{t_{\mathrm{MAX}}} \frac{T(t)-100}{\omega} d t+\int_{t_{\mathrm{MAX}}}^{t_{F}} \frac{T^{\prime}(t)-100}{\omega} d t\right]
\end{aligned}
$$$$
R_{0}=\frac{t}{\rho r^{2}((1-0.5 \ln \varphi) / 2 M \varphi D \Delta C)} * e^{((T-100) / 14.75) 10^{-p H}}
$$

Model that explains the severity factor in function of chip size and processing time taking into account the diffusion of liquid into LCMs.

Relationship between the severity factor and the viscosity of slurries made from sewage sludge during hydrothermal processing.

Model that explains the time needed for the chips to reach the desired temperature of wood with round or square cross section 1 and rectangular cross section 2 in hydrothermal processing. $\mu=2.755 \times 10^{5} \times R_{0}^{0.8250}$

$$
\begin{aligned}
& \text { (1) } t=a\left(T_{h t}\right)^{b}\left(T_{c t r}\right)^{c}\left(T_{\text {init }}\right)^{d} D^{e} M^{f} G^{g} \\
& \text { (2) } t=a\left(T_{h t}\right)^{b}\left(T_{c t r}\right)^{c}\left(T_{\text {init }}\right)^{d}(T H)^{d} W^{f} M^{g} G^{h}
\end{aligned}
$$

$t_{\mathrm{MAX}}(\mathrm{min})$ is the time needed to achieve

maximum autohydrolysis temperature, $t_{F}(\mathrm{~min})$ is

the time needed for the whole heating-cooling

period, $T(t)$ and $T^{\prime}(t)$ stand for the temperature profiles in heating and cooling, respectively and $\omega$ is an empirical parameter.

$t$ is the time of reaction (min), $T$ is the temperature Hosseini et al. $\left({ }^{\circ} \mathrm{C}\right), D$, is the diffusion coefficient, $\rho$ is the density [84] of the fluid, $\phi$ is thevoid fraction (porosity), $r$ is the particle radius ( $\mathrm{mm}), M$ is the molecular weight and $\Delta C$ is the concentration gradient.

$\mu$ is viscosity (Pa s/s) and $R_{0}$ is the severity parameter.

Yanagida et al. [107]

$t$ is the time estimated ( $\mathrm{min}$ ) for the center reach Simpson [108] target temperature, $T_{h t}$ is the heating temperature $\left({ }^{\circ} \mathrm{F}\right), T_{c t r}$ is the target center temperature, $T_{\text {init }}$ is the initial wood temperature $\left({ }^{\circ} \mathrm{F}\right)$, $\mathrm{D}$ is de diameter of round cross section (in), $\mathrm{TH}$ is the thickness of rectangular board (in), $W$ is the width of rectangular board (in), $M$ is the moisture content (\%), $\mathrm{G}$ is the specific gravity, $\mathrm{a}-\mathrm{h}$ are the regression coefficients.

Where $\rho$ is the density, ris the particle, $\phi$ is the porosity, $D$ is the diffusion coefficient, $M$ is the molecular weight and $\Delta C$ is the concentration gradient.

$T_{2}$ is the temperature $\left({ }^{\circ} \mathrm{C}\right)$ needed for compensate Hosseini et al. the particle size increase, $T_{1}$ is the initial LCMs temperature which can be assumed as $20{ }^{\circ} \mathrm{CC} r_{1}$ and $r_{2}$ are the radius (cm), $R_{1}$ and $R_{2}$ are de severity factor.
Hosseini et al. [109]
Romaní et al.

(a)

\author{
(1)
} process and LCMs characteristics (assuming that LCMs have a porous structure) in hydrothermal process.

Model for calculating the temperature needed for different particle sizes. Temperature as a function of severity factor and radius in hydrothermal processing. 

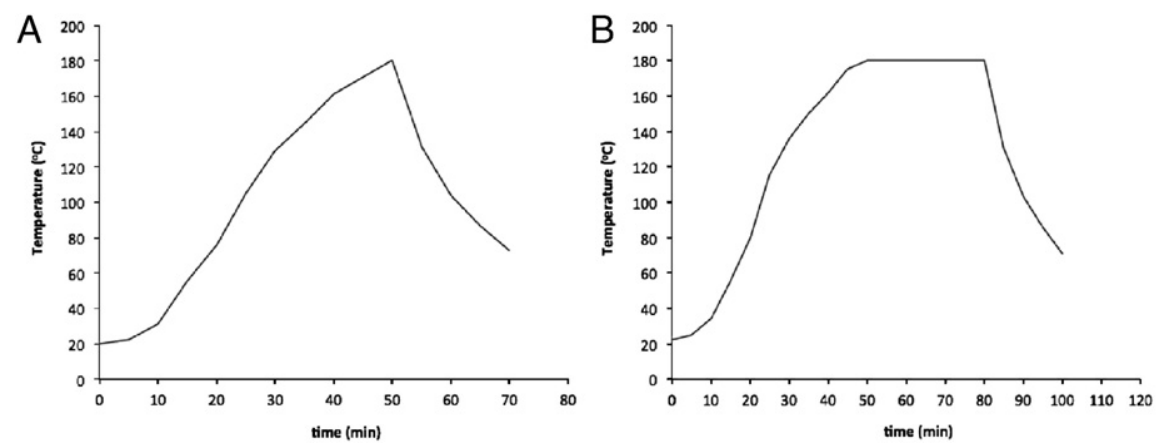

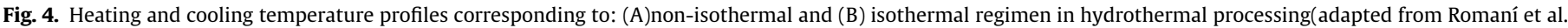
[104]; Ruiz et al. [69]).

generally used to correlate the effects of operational conditions (i.e., temperature, residence time, particle size, $\mathrm{pH}$ ) on hemicellulose solubilization. It was initially used to control the pulping process in the paper industry, but it was reintroduced for comparison of hydrothermal processing pretreatment severities on LCMs [110-112]. Hydrothermal processing is appropriate for hemicellulose depolymerization and, for a detailed understanding of the chemical reactions that occur during hydrothermal processing, the development of kinetic models enables a deeper insight on the several phenomena involved and provides mathematical equations suitable for simulation, optimization and design of operational strategies. Mathematical models based on pseudofirst order kinetics have been successfully employed for hydrolysis modeling. Garrote et al. [113] and Gullón et al. [45] suggested the kinetic reaction of hydrothermal processing using rye straw as raw material based on the following considerations: (1) a small part of the glucan fraction was degraded into glucooligosacharides, which were partially hydrolyzed to give glucose; (2) hemicelluloses were partially depolymerized along hydrothermal processing; (3) xylan was made up of two fractions (susceptible/non-susceptible to hydrothermal processing; the susceptible xylan fraction was hydrolyzed to give high molecular weight xylooligomers, which can be further decomposed into low molecular weight xylooligomers, subsequent xylose and promote dehydrated of xylose to furfural; (4) arabinosyl and acetyl groups hydrolysis are easily cleaved from xylan; (5) uronic acid fraction was made up of two fractions (susceptible/non-susceptible to hydrothermal processing). Similar considerations of xylan kinetic model were proposed by Garrote et al. [114] using corncob as raw material as follows:

Hemicellulose $\stackrel{K_{i}}{\rightarrow}$ oligosaccharide $\stackrel{K_{i+1}}{\rightarrow}$ monosaccharides

$$
\stackrel{K_{i+2}}{\rightarrow} \text { degradation product }
$$

In order to provide a quantitative interpretation of xylan degradation under non-isothermal conditions Garrote et al. [115] proposed a modification, where some degradation of the slow-reacting fraction occurred at high temperatures. Nabarlatz et al. [116] developed a model for the kinetics of xylan depolymerization. The model assumes that the composition of each of the two xylan fractions in the LCMs does not change with the conversion, there is not direct formation of monomers (i.e., xylose, arabinose and acetic acid), the monomers are formed solely by depolymerization of the oligomers and the rates of monomer formation from oligomers are independent of the molar mass, structure and the oligomers. Carvalheiro et al. [63] proposed two models for xylan and arabinan degradation assuming that furfural was formed from both pentoses. Zhuang et al. [117] reported the kinetic modeling of xylan, measuring the oligosaccharides and monosaccharides as reducing sugar and the kinetic model was thus adopted as:

Xylan $\stackrel{K_{1}}{\rightarrow}$ reducing sugars $\stackrel{K_{2}}{\rightarrow}$ degradation products

In a recent work Martinez et al. [118] proposed kinetic models for arabinan and acetyl groups based on sequential and parallel, irreversible and first-order reactions with Arrhenius-type temperature dependence and reported that the kinetic models provided a good prediction for the data of reaction liquors as function of the operational conditions. An overview about the kinetic modeling of cellulose hydrolysis can be found by Zhao et al. [119] and Rogalinski et al. [100] as follows:

Cellulose $\stackrel{K_{1}}{\rightarrow}$ oligosaccharides $\stackrel{K_{2}}{\rightarrow}$ hexoses $\stackrel{K_{3}}{\rightarrow}$ degradation products

\subsection{Effect of hydrothermal processing on cellulose}

Cellulose is the most abundant biopolymer that can be obtained from numerous LCMs resources and there is a clear opportunity to develop commercial processes that could generate products that are needed at very high volumes and low selling price. One strategy to fractionation of LCMs is hydrothermal processing, since hemicelluloses are depolymerized into soluble products, whereas the solids from hydrothermal processing are enriched into cellulose and lignin. A variety of applications can be visualized for this phase from hydrothermal processing of LCMs. Currently, the most promising approach for using LCMs is enzymatic hydrolysis of the cellulose content after pretreatment for second generation bioethanol production (see Table 3). Pretreatment is required to alter the structure and chemical composition due to the robustness of LCMs. Hydrothermal processing as pretreatment caused re-localization of lignin on the surface of LCMs [127], thus enzyme accessibility to the LCMs structure in the pretreated material is favoured, increasing the potential of cellulose saccharification. Moreover, physical changes that improve enzymatic saccharification include an increase in pore size to enhance enzyme penetration and an increase in accessible area that has been shown to correlate well with the susceptibility of these substrates to enzyme saccharification using hydrothermal processing as pretreatment [27,95,128-134]. Table 4 shows the enzymatic saccharification yield using hydrothermal processing as pretreatment at different operational conditions and demonstrate the ability of this technology to make LCMs accessible to enzymes. Hydrothermal processing is a promising pretreatment for second generation bioethanol production, considering its great versatility and feasibility in the fractionation of LCMs, that it is a key in the development of biorefineries, but the large-scale commercial utilization of this pretreatment has still not been implemented. However, there are few companies that 
Table 3

Production of bioethanol using hydrothermal processing as pretreatment under different operational conditions and raw materials.

\begin{tabular}{|c|c|c|c|c|c|}
\hline Raw material & Temp. $\left({ }^{\circ} \mathrm{C}\right)$ & Time (min) & Particle size & Ethanol Yield (\%) & Reference \\
\hline Wheat straw & 195 & $6-12$ & - & 89 & Petersen et al. [14] \\
\hline Rice Straw & 180 & 30 & $250-420 \mu \mathrm{m}$ & 100 & Yu et al. [25] \\
\hline Switchgrass & 210 & 15 & - & 72 & Suryawati el at. [17] \\
\hline Eucalyptus globulus & 230 & - & $8 \mathrm{~mm}$ & 86.4 & Romaní et al. [26] \\
\hline Wheat straw & 214 & 2.7 & $0.5-2 \mathrm{~mm}$ & 90.6 & Pérez et al. [19] \\
\hline Corn stover & 195 & 10 & - & 61.2 & $\mathrm{Xu}$ et al. [120] \\
\hline Sugar cane bagasse & 220 & 2 & - & 85 & Walsum et al. [121] \\
\hline Wheat straw & 200 & 40 & $0.5-2 \mathrm{~mm}$ & 96 & Pérez et al. [122] \\
\hline Poplar nigra & 240 & 60 & $2-5 \mathrm{~mm}$ & 60 & Negro et al. [123] \\
\hline Sweet sorghum bagasse & 190 & - & - & 74 & Rohowsky et al. [124] \\
\hline T85 bermudagrass & 230 & 2 & $500 \mu \mathrm{m}$ & 70 & Brandon et al. [125] \\
\hline Ulex europæus & 230 & - & $8 \mathrm{~mm}$ & 82 & Ares-Peón [126] \\
\hline
\end{tabular}

Table 4

Enzymatic Saccharification of pretreated solids with hydrothermal processing as pretreatment.

\begin{tabular}{|c|c|c|c|c|}
\hline Raw material & $\begin{array}{l}\text { Temp. } \\
\left({ }^{\circ} \mathrm{C}\right)\end{array}$ & $\begin{array}{l}\text { Time } \\
(\mathrm{min})\end{array}$ & $\begin{array}{l}\text { Saccharification } \\
\text { yield (\%) }\end{array}$ & Reference \\
\hline $\begin{array}{l}\text { Prairie cord } \\
\text { grass }\end{array}$ & 210 & 10 & 94.53 & $\begin{array}{l}\text { Cybulska et al. } \\
\text { [27] }\end{array}$ \\
\hline Oil palm fronds & 178 & 11.1 & 92.78 & Goh et al. [135] \\
\hline $\begin{array}{l}\text { Coastal Bermuda } \\
\text { grass }\end{array}$ & 150 & 60 & 67.4 & Lee et al. [136] \\
\hline Corn stover & 190 & 15 & 69.6 & Zeng et al. [137] \\
\hline Wheat straw & 195 & 3 & 72 & $\begin{array}{l}\text { Thomsen et al. } \\
{[138]}\end{array}$ \\
\hline Switchgrass & 200 & 10 & 74.4 & $\begin{array}{l}\text { Hu and Ragauskas } \\
\text { [139] }\end{array}$ \\
\hline $\begin{array}{l}\text { Tamarix } \\
\text { ramosissima }\end{array}$ & 200 & 180 & 88 & Xiao et al. [140] \\
\hline $\begin{array}{l}\text { Eucalyptus } \\
\text { grandis }\end{array}$ & 200 & 20 & 96.6 & Yu et al. [141] \\
\hline Barley husks & 212 & - & 100 & $\begin{array}{l}\text { Ares-Peón et al. } \\
{[142]}\end{array}$ \\
\hline $\begin{array}{r}\text { Eucalyptus } \\
\text { globulus }\end{array}$ & 230 & - & 97.9 & $\begin{array}{l}\text { Romaní et al. } \\
{[104]}\end{array}$ \\
\hline Wheat straw & 180 & 30 & 90.88 & Ruiz et al. [143] \\
\hline Prairiecordgrass & 190 & 1 & 81.28 & $\begin{array}{l}\text { Cybulska et al. } \\
{[144]}\end{array}$ \\
\hline $\begin{array}{c}\text { Sugarcane } \\
\text { bagasse }\end{array}$ & 190 & 10 & 69.2 & Silva et al. [145] \\
\hline
\end{tabular}

have operated as demo-scale plants. For example, Inbicon has been built a in Kalundborg Denmark using wheat straw as raw material under hydrothermal pretreatment conditions at 180$200{ }^{\circ} \mathrm{C}$ for $10-20 \mathrm{~min}$ with steam. This demo-scale plant is according to the Integrated Biomass Utilization System (IBUS)concept that resulted in a continuous hydrothermal pretreatment [146-149]; moreover the Inbicon process has been recently reviewed by Larsen et al. [150]. In respect to the technoeconomic study of hydrothermal process as pretreatment; only few analyses have been reported. Treasure et al. [151]reported an analysis of bioethanol and electricity production from hardwood and softwood as raw material and autohydrolysis as pretreatment, they concluded that the financial performance of autohydrolysis pretreatment appears to be most sensitive to ethanol yield, followed by capital investment and raw material cost. Recently Littlewood et al. [152] showed a minimum ethanol selling prices of $£ 0.474 / \mathrm{L}$ ( $\$ 2.85 / \mathrm{gal}$ ) for hydrothermal pretreatment, also reported that the raw material (wheat straw) prices and the enzymes costs were the main contributors for the minimum ethanol selling prices in all scenarios studied and within the pretreatment area alone, the hydrothermal pretreatment was the lowest total area cost.
On the other hand, after hydrothermal processing the cellulose shows a little degradationat different temperatures $>230{ }^{\circ} \mathrm{C}$. In a recent work, Romaní et al. [26] reported decreases of $5.29 \%$ and $19.55 \%$ of cellulose present in pretreated solids at $240{ }^{\circ} \mathrm{C}$ and $250{ }^{\circ} \mathrm{C}$, respectively, defining the operational range where partial cellulose degradation began to take place. According to Sakaki et al. [153] cellulose started to degrade in hexoses and oligosaccharides above $230{ }^{\circ} \mathrm{C}$ and almost all cellulose was decomposed at $295^{\circ} \mathrm{C}$. Jin et al. [154] reported that cellulose hydrolyzes into glucose in $2 \mathrm{~min}$ at $300^{\circ} \mathrm{C}$, but that the glucose decomposes in $30 \mathrm{~s}$ under the same conditions. Other type of solid residues which contain mainly cellulose and lignin after hydrothermal processing are the raw material for pulp and paper marking [155]. Caparrós et al. [48] reported similar characteristics of paper sheets obtained from sequencing hydrothermal processing and ethanol pulping to those obtained by soda pulp. Vila et al. [68] showed the susceptibility of hydrothermally treated solids to kraft processing pulp which provided cellulose pulps with low kappa numbers, highly susceptible to alkaline oxygen bleaching. Romaní et al. [9] used the solids (cellulose + lignin) obtained after hydrothermal processing for delignification and improved the enzymatic saccharification of cellulose from Eucalyptus globulus. According to Alfaro et al. [156] the cellulose pulp with hydrothermal processing reduces kappa number, viscosity and decreases paper strength. Caparrós et al. [157] evaluated the solid phase obtained from hydrothermal processing using the organosolv process for produced paper sheets, analyzing the influence of operational variables on the viscosity, tensile index, burst index, tear index and brightness obtaining suitable characteristics of paper sheets.

\subsection{Effect of hydrothermal processing on hemicellulose}

The hemicellulose is the second most abundant polysaccharide in nature and is made up of amorphous heteropolysaccharides constituting $14-50 \%$ of the raw LCMs dry weight. Hemicellulose consists of various structural units, including five-carbon (xylose and arabinose) and six-carbon sugars (mannose, galactose, glucose), which can be substituted with phenolic, uronic or acetyl groups. The most abundant block of hemicellulose in hardwoods and many agricultural residues is xylan (made up mainly of xylose units) $[43,158,159]$. Hydrothermal processing is a suitable method for hemicellulose depolymerization, under selected operational conditions as hemicellulose can be almost totally removed from LCMs (see Fig. 2) [160], being decomposed into valuable soluble products such as oligosaccharides, monosaccharides, sugar-decomposition products (such as furfural or hydroxymethylfurfural) and acetic acid (from acetyl groups hydrolysis). Furthermore, when a xylan is subjected to hydrothermal processing under mild temperature, high-molar mass xylo-oligosaccharides 
(XOS) and xylose are produced, being the major products derived from hemicellulose present in the liquor phase [22,45,161]. Under harsh operational conditions, xylose can be dehydrated to furfural, and furfural can be converted into degradation products [115]. Xylooligosaccharides are bioactive molecules with high-added value and have great prebiotic potential making them useful as ingredients for functional foods. From a nutritional point of view, XOS are usually considered to be nondigestible oligosaccharides [116,162-166]. Recently, solubilization studies of XOS from LCMs by hydrothermal processing have shown the efficiency of this technology to improve the yields of extraction. Gullón et al. [45] reported a yield of $69.2 \%$ of XOS with respect to the initial xylan at $208^{\circ} \mathrm{C}$, using rye straw as raw material. Nabarlatz et al. [167] reported $58.3 \%$ of crude XOS after hydrothermal processing at $179{ }^{\circ} \mathrm{C}$ for 23 min using ultra-filtration for the purification of XOS. Carvalheiro et al. [164] also reported a similar yield of $61 \%$ of XOS at $190{ }^{\circ} \mathrm{C}$ after 5 min, using brewery's spent grain. According to Garrote et al. [168], the hydrothermal processing in non-isothermal reaction conditions produced $23.2 \mathrm{~g}$ of oligosaccharides $/ 100 \mathrm{~g}$ of oven-dried corncobs at $202{ }^{\circ} \mathrm{C}$. Boussarsar et al. [92] showed that it is possible to obtain an acceptable xylose extraction yield and low degradation of sugar monomers for $2 \mathrm{~h}$ at $170{ }^{\circ} \mathrm{C}$. Kabel et al. [165] and Carvalheiro et al. [164] in previous studies for the production of XOS by hydrothermal processing of brewery's spent grain reported that several oligosaccharide mixtures of different molecular weight distributions were obtained depending on temperature and reaction time (severity of reaction conditions). Longer reaction times led to a decreased amount of oligosaccharides and an increase of the concentration of monosaccharides, acetic acid and sugar decomposition products. Montané et al. [169] used active carbon as an alternative for the purification of XOS produced by hydrothermal processing. Vegas et al. [170] used ultra- and nanofiltration for the purification of oligosaccharides from rice husk hydrothermal processing liquors, reporting that it is possible to recover about $90 \%$ of the XOS present in hydrolysis liquors. Different reactor configurations have been used for improving the recovery of hemicellulose. According to Liu and Wyman [99], xylose yield improved from 60 to $82 \%$ with an increase in the fluid velocity from 2.8 to $10.7 \mathrm{~cm} / \mathrm{min}$ on a flowthrough reactor using corn stover as raw material at $200{ }^{\circ} \mathrm{C}$ after $8 \mathrm{~min}$ residence time. Makishima et al. [103] found an effective recovery of hemicellulose using a tubular type reactor at $200{ }^{\circ} \mathrm{C}$ for $10 \mathrm{~min}, 82 \%$ of xylan fraction recovered as mixture of xylose, XOS and higher XOS with polymerization degree higher than 10. Garrote and Parajó [171] reported that more than $80 \%$ of the initial xylan can be removed from wood with a conversion in XOS up to $65 \%$ of the initial xylan in a batch reactor. Other important point is the deacetylation of hemicellulose during the hydrothermal processing; Garrote et al. [172] studied the time course of acetyl groups' hydrolysis from both xylan and xylan degradation products, and their relationship with the concentration of acetic acid. Xylitol, a pentitol derived from xylose by reduction has technological and biological properties, such as high sweetening power, anticariogenic properties and suitability for consumption by diabetics, that foster its utilization in the food industry. XOS produced in hydrothermal processing can be used as a source of xylose for the production of xylitol. However, these XOS cannot be directly metabolized by microorganisms. In order to prepare fermentation media for the production of xylitol from hydrothermal processing liquors, XOS must be first converted into monosaccharides by either acid or enzyme catalyzed reactions, this process providing a way to obtain xylose solutions. Rivas et al. [173] used the sequence (hydrothermal processing-posthydrolysis) with corncob hydrolysate and observed an increase in the productivity and yield of xylitol in comparison with the results obtained in a fermentation media made by the conventional acid hydrolysis pretreatment. Duarte et al. [174] produced xylitol and arabitol from brewery's spent grain hydrolysate using the sequence (hydrothermal processing-posthydrolysis) by Debaryomyces hansenii without any detoxification treatment. Garrote et al. [175,176] used corncobs and Eucalyptus globulus as raw material in hydrothermal processing and concluded that generation of xylose solution to be used as fermentation media through sequential stages of hydrothermal processingposthydrolysis, shows favorable features in terms of substrate conversion, reaction, selectivity and low inhibitor concentration.

Vázquez et al. [177] reported a concentration of $24 \mathrm{~g}$ xylose/L, using the sequence (hydrothermal processing-enzymatic posthydrolysis) using corncobs as raw material at $175^{\circ} \mathrm{C}$ for $20 \mathrm{~min}$, the advantage being that the hydrolysate after this sequence is free of sugar degradation products and the acetic acid concentration could be reduced, thus improving their potential fermentability. XOS can also be synthesized and used as thermoplastic compounds for biodegradable plastics, water-soluble films, coatings and capsules [178]. Glasser et al. [179] produced a thermoplastic from the chemical modification of pentose-rich oligosaccharides such as xylose. Lindblad et al. [180] produced hydrogels from hemicellulosic oligosaccharides and 2-hydroxyethylmethacrylate. In a recent work, Ruiz et al. [71] reported the viability of the application of the hemicellulosic liquid phase, recovery after hydrothermal process, in the production of polymeric blend films. The need to replace traditional plastics due the negative environmental impact caused, has increased the interest on the development of biodegradable polymers. Polylactic acid (PLA) is a biodegradable polymer with thermoplastic character, produced by polymerization of lactic acid (which can be obtained by fermentation of sugars derived from LCMs), that finds applications in such fields as packaging, disposable goods or textile fibres. Vila et al. [181] evaluated rice husks and Eucalyptus globulus in hydrothermal processing for the production of xylose-based culture media for lactic acid production and the application of the fiber contained in the pretreated solids for making PLA-based biodegradable composites. In a recent work González et al. [182] produced biodegradable biocomposites from Citysus scoparius using hydrothermal processing, obtaining a maximum concentration of oligomers ( $71 \%$ of the initial xylan) at $215^{\circ} \mathrm{C}$ and a solid phase (cellulose+lignin) suitable as a reinforcement for PLA-based composites, the composites showing better stiffness compared with pure PLA. Other important application of hemicellulosic liquid phase after hydrothermal pretreatment is the production of xylanases [70].

\subsection{Effect of hydrothermal processing on lignin}

Lignin is the most abundant aromatic heterogeneous polymer formed by phenolic compounds and their precursors are three aromatic alcohols namely, (1) p-coumaryl, (2) coniferyl and (3) sinapyl alcohols, which are bonded together with over two-third being ether bonds $(\mathrm{C}-\mathrm{O}-\mathrm{C})$ and the rest being $\mathrm{C}-\mathrm{C}$ bonds. The respective aromatic constituents in the polymer are called $p$ hydroxyphenyl $(H)$, guaiacyl $(G)$ and syringyl $(S)$, the structure of lignin suggesting that it can be a valuable source of chemicals, particularly phenolics [8,183-186]. Lignin is always associated with hemicelluloses, not only as physical admixtures, but also through covalent bonds. During the hydrothermal processing lignin and lignin-hemicellulose linkages can undergo degradation, partial depolymerization and profound re-localization. Moreover, the fraction of solubilized lignin depends on the operation conditions (severity of reactions conditions) and on the raw material (LCMs) $[28,66,127]$. Lora and Wyman (1978) and Bobleter and Concin (1979) cited by Garrote et al. [28] and Zhang et al. [187] suggested a two-phase mechanism for lignin reaction: (1) a very fast reaction where lignin fragments with low molecular weight and high reactivity are solubilized by breaking lignin-carbohydrate bonds into soluble fragments; (2) a slower 
reaction where the soluble fragments react with one another by recondensantion and lignin repolimerization, which also occurs in the presence of the organic acids liberated in the hydrothermal processing. Soluble lignin being aromatic and possessing many chromophoric structural units strongly absorbs ultraviolet (UV) light and the absorbance at either 205 or $280 \mathrm{~nm}$ is the basis of several techniques for the quantitative determination of soluble lignin $[188,189]$. The partial depolymerization of lignin and breaking of lignin-hemicellulose linkages produced part of the phenolics present in the hydrothermal processing liquors $[66,190]$. Using hardwood as raw material, Marchessault et al. [191] reported that the ether linkages of lignin are cleaved during hydrothermal processing causing a decrease in molecular weight and an increase in phenolic content. These phenolics, considered as the byproducts of LCMs hydrothermal processing are an attractive source for natural antioxidants and might have potential applications as food additives [183,192]. The extracts and compounds derived from soluble lignin can be selectively extracted from hydrothermal processing liquors with ethyl acetate. This phenolic-rich extract contains a variety of potentially valuable compounds with antioxidant, antimicrobial and biological activities comparable to that of synthetic antioxidants [193-195]. Several lignin-derived products have been identified. Garrote et al. [22] reported benzoic, gallic and cinnamic acids in the liquor after hydrothermal processing at $216{ }^{\circ} \mathrm{C}$ using barley husk as raw material. Conde et al. [196] found that hydroxytyrosol, homovanillyl alcohol, oleuropein, syringaldehyde, tyrosol, 3,4-dihydroxybenzaldehyde were the major phenolic compounds in the soluble fraction from the hydrolyzates of barley husks obtained by hydrothermal processing. In a recent work, Tsubaki et al. [197] used microwave as an alternative heating source for tea residues autohydrolysis and reported that vanillin, vanillic acid, dihydroconiferyl alcohol and guaiacol are degradation compounds originated from guaiacyl $(G)$ units of lignin. In a similar way, syringaldehyde, syringic acid and sinapaldehyde were considered to be originated from syringyl (S) units of lignin. Conde et al. [198] reported that gallic acid, 3,4-dihydroxybenzaldehyde, vanillic acid, syringic acid, vanillin and $p$-coumaric acid were the major low molecular weight phenolics present in the refined media using barley husks as raw material. According to Castro et al. [195], the major compounds founded in lignin-derived fractions were syringaldehyde, vanillin, 4-formyl benzoic acid methyl ester, desaspidinol, syringol, guaiacol, homosyringic acid and methoxyeugenol using Olea europea wood as raw material. Pourali et al. [199] used subcritical water conditions and reported the production of eleven phenolic compounds (caffeic, ferulic, gallic, gentisic, p-coumaric, p-hydroxybenzoic, protocatechuic, sinapic, syringic, vanillic acids and vanillin) and concluded that the content of phenolic compounds increased with the temperature. Many beneficial effects on human health have been attributed to simple phenolics: oleuropein, hydroxytyrosol, caffeic acids (prevention of cardiovascular diseases); hydroxytyrosol, tyrosol, vanillin, vanillic acid, caffeic acids (prevention of tumoral diseases); $p$-coumaric acid, caffeic acid, ferulic acid (protection against LDL lipoprotein oxidation); gallic acid (skin protective ability); vanillin, (anti-inflammatory) [66,183,200-203]. In regard to antioxidant activity, Tsubaki et al. [204] reported the production of polyphenols above $200{ }^{\circ} \mathrm{C}$, obtaining strong antioxidant activity using tea residues as raw material and microwave heating. Conde et al. [198] reported that the hydrothermalextraction process was suitable for obtaining antioxidants, but the limited mass fraction of phenolics and the values determined for antioxidant activity, suggest that further purification would result in products of improved quality. Akpinar et al. [205] used ultra-filtration as an alternative to ethyl acetate extraction and reported that sunflower stalk liquors had higher antioxidant activity than wheat straw, the hydrothermal processing being carried out at $160{ }^{\circ} \mathrm{C}$ for $1 \mathrm{~h}$. Tsubaki et al. [206] also studied the extraction of phenolic compounds and reported that antioxidant activity increased in good correlation with the increase in the concentration of phenolic compounds in the extracted hydrothermal processing liquor. Garrote et al. [30] reported that the antioxidant activity of ethyl acetate extracts isolated from Eucalyptus globulus and corncob hydrothermal processing liquors showed a strong dependence on the hydrothermal conditions. Moreover, Pourali et al. [199] found that phenolic compounds could be selectively produced by temperature variations. Conde et al. [192] studied the in vitro antioxidant capacities of the ethyl acetate extract from hydrothermal processing using different LCMs and reported that the antioxidant capacities were comparable or higher than the ones of synthetic compounds, similar results being obtained by Castro et al. [195] using Olea europea wood at temperatures in the range of $190-240^{\circ} \mathrm{C}$. On the other hand, Li and Gellerstedt [207] reported that the solid residues obtained after hydrothermal processing showed improved susceptibility towards delignification with organic solvents. According to Hongzhang and Liying [208] the sequential application of hydrothermal processing-organosolv pretreatment is an effective process for the extraction of lignin (delignification) with reasonable yields and purity. Ruiz et al. [8] evaluated delignification using the sequence hydrothermal processing-organosolv process and concluded that the temperature and time as well as chemical structure were variables that showed a strong influence on lignin precipitation. Romaní et al. [9] used the sequence hydrothermal processing-organosolv process for delignification, resulting in an improved enzymatic saccharification.

\section{Hydrothermal processing of aquatic biomass}

Recently, aquatic biomass including macro- and micro-algae is gaining wide attention as an alternative renewable source of biomass, mainly because of their content of functional components such as oils, proteins and carbohydrates. Similarly to LCMs, it is necessary to find an alternative that allows the fractionation of their main components. The hydrothermal processing of aquatic biomass is of considerable interest as this technology is ideally suited to high moisture content feedstocks such as macro and microalgae biomass. Presently, there are few literature reports on hydrothermal processing of aquatic biomass. The subsequent sections will deal with the main applications of hydrothermal processing using macro- and micro-algae as raw material.

\subsection{Hydrothermal processing of macroalgae}

Macroalgae have a large potential as raw material for energy production and chemicals for food and medical industries. However, so far, most of the research has been concentrated on converting terrestrial biomass. A relatively new concept includes the utilization of marine biomass, and demands an assessment of how this marine biomass can contribute to the total biomass resources [209]. Oceans and seas cover over 70\% of the Earth's surface, offering the possibility of sustainable cultivation of a vast potential biomass feedstock. The use of macro-algae or seaweeds biomass has several advantages including: (a) in the future, low fluctuations in biomass demand are expected due to overpopulation; (b) feasibility of fast growing rate in the open ocean; (c) higher photosynthetic activity (6-8\%) than terrestrial biomass (1.8-2.2\%); (d) no limitation by water and to a lesser extent temperature; and e) low costs of collection and null environmental damage [210-212]. The production of seaweeds and other aquatic plants reached 16.0 million tons in 2007, of which 
aquaculture produced 14.9 million tons with a value of USD 7.5 billion [213], making annual primary production rates (grams/ $\left(\mathrm{m}^{2} \cdot\right.$ year $\left.)\right)$ higher for the major marine macroalgae than for most terrestrial biomass. Macroalgae can be subdivided into blue algae (Cyanophyta), green algae (Chlorophyta), brown algae (Phaeophyta) and red algae (Rhodophyta), the main regions for cultivation on a mass scale being the Far East, and on a smaller scale, Europe [211]. Nowadays, seaweeds applications are focused on human foods, cosmetics and fertilizers and for the extraction of many useful industrial chemicals such as phycocolloids (e.g., alginates), being also a potential source of long- and short-chain chemicals with medicinal and industrial application as biofuels $[213,214]$. Moreover, conversion of macroalgae into biofuel has been focused on the production of biogas by anaerobic digestion, but no thermochemical treatment was carried out over the raw material before the fermentation processes [215]. Recent studies have also been focused on the utilization of the sugars present in seaweeds (mannitol and laminarin for brown algae) for the production of bioethanol by fermentation [216-219]. However, research on the application of hydrothermal processing to macroalgae is limited [220,221]. The excellent solvent properties of water as a reaction medium and the usually high moisture content of macroalgae make hydrothermal treatment a promising processing technology for the direct use of macroalgae in the production of biofuels and high added-value compounds [222-227]. Hot water is used at temperatures from 100 to $374{ }^{\circ} \mathrm{C}$, under high pressure, usually from 10 to $60 \mathrm{bar}$, corresponding to conditions below the water critical point. In the case of macroalgae, hydrothermal processing involves the reaction of marine biomass and water at elevated temperatures and pressures and its application has been demonstrated with and without the presence of catalysts for a wide range of biomass origins. Under these conditions biomass is decomposed to form new products, including a bio-crude fraction, a char fraction, a water fraction and a gaseous fraction [224]. Looking for alternatives to seaweeds application, mostly used in food and cosmetic area, preliminary experiments using the green macroalgae Chaetomorpha linum for biodiesel production were described by Aresta et al. [228]. Two techniques were compared: supercritical carbon dioxide $\left(\mathrm{sc}-\mathrm{CO}_{2}\right)$ and hydrothermal processing and it was verified that hydrothermal processing was more efficient with a higher amount of oil extracted at plateau temperatures of $350-395^{\circ} \mathrm{C}$. Hydrothermal processing to bio-oil production was also carried out with the green seaweed Enteromorpha prolifera in a batch reactor evaluating the effects of the temperature, reaction timeand $\mathrm{Na}_{2} \mathrm{CO}_{3}$ catalyst. A maximum bio-crude yield of $23 \mathrm{wt} \%$ with a Higher Heating Value (HHV) of $29.89 \mathrm{MJ} / \mathrm{kg}$ was obtained at $300{ }^{\circ} \mathrm{C}$ and 30 min with 5 wt\% $\mathrm{Na}_{2} \mathrm{CO}_{3}$. The obtained bio-oil was a complex mixture of ketones, aldehydes, phenols, alkenes, fatty acids, esters, aromatics, and nitrogen containing heterocyclic compounds [225]. Anastasaki and Ross [212] evaluated the hydrothermal processing of Laminaria saccharina brown seaweed with and without the addition of catalyst $(\mathrm{KOH})$ in order to maximize the bio-crude yield. A maximum bio-crude yield of $19.3 \mathrm{wt} \%$ was obtained with a $1: 10$ biomass: water ratio at $350{ }^{\circ} \mathrm{C}$ and a residence time of $15 \mathrm{~min}$ without the presence of the catalyst; the most important variables were considered to be temperature and reactor loading. The obtained bio-crude showed a HHV of $36.5 \mathrm{MJ} / \mathrm{kg}$, a slightly lower value than the reported for crude petroleum $(42.7 \mathrm{MJ} / \mathrm{kg})$ [224,226]. Furthermore, analysis of the aqueous phase indicates that mannitol and laminarin present in brown seaweed are dissolved, suggesting a further utilization of the high sugar aqueous stream in a fermentative process to produce bioethanol. It was also established that the addition of the catalyst caused a reduction of sugars presence in this stage. Marine algae biomass conversion into ethanol is an option to be considered since some algae hydrolysates contain more total carbohydrates and hexose sugars than some terrestrial LCMs. However, only few studies on this matter have been reported. Kim et al. [229] evaluated ethanol production from several macroalgae using Escherichia coli KO11 and Saccharomyces cerevisiae strains for sugar fermentation. Hydrothermal processing for the preparation of algal hydrolyzates was carried at $121^{\circ} \mathrm{C}$ for $15 \mathrm{~min}$ in the presence of acid catalyst $\left(\mathrm{H}_{2} \mathrm{SO}_{4}\right)$. Under the evaluated conditions Laminaria japonica hydrolysate contained a high amount of mannitol (30.54\%) making it a cost-effective substrate for microbial ethanol production. Escherichia coli KO11 ethanol yield was $0.4 \mathrm{~g}$ ethanol/g of sugars, while the yeast strain was unable to ferment mannitol, this being attributed to catalyst application in hydrothermal processing.

As an alternative to subcritical hydrothermal processing, there is the possibility of applying supercritical extraction. A supercritical fluid is obtained when a fluid is forced to a pressure and temperature above its critical point (for water about to $374{ }^{\circ} \mathrm{C}$ ) - its density is similar to a liquid, its viscosity is similar to a gas and its diffusivity is intermediate between the two states. Thus, the supercritical state is defined as a condition in which liquid and gas are indistinguishable from each other [227]. Schumacher et al. [223] studied the supercritical hydrothermal processing conversion in several seaweed species based in the principle that water gasification appears to be a useful technology for biomass with a high humidity content (up to 90\%). Thus, biomass feedstock was gasified with supercritical water at $500{ }^{\circ} \mathrm{C}$ for $1 \mathrm{~h}$. Even though the coke yields were significantly lower than those obtained with lignocellulosic and protein wastes, the total gas yields were higher than the reported for these materials, because algae polysaccharides and proteins are decomposed at 200 to $400{ }^{\circ} \mathrm{C}$. The gaseous species detected were mainly hydrogen, methane and carbon dioxide where the highest values for $\mathrm{H}_{2}$ and $\mathrm{CH}_{4}$ were 16 and $104 \mathrm{~g} / \mathrm{g}$ of seaweed, respectively. Additionally, the aqueous phase contained glycolic, formic and acetic acids and phenols. Microwaves as an alternative-heating source have been successfully applied for extraction of numerous biologically active compounds from a wide variety of natural resources, because it is characterized as a selective, efficient and environmental friendly process. This technique consists in a rapid delivery of energy to the total volume and subsequent rapid heating into the material structure accelerating the solubilization of compounds [230,231]. Polar solvents have permanent dipole moment and can absorb microwave radiation and water as a polar compound can absorb the microwave energy and transfer it to the sample, having as advantages over the organic solvents being a secure and ecologic reagent. Microwave-assisted hydrothermal processing is a technique that should be considered for the extraction of seaweeds' polysaccharides since the main sugars present in macro-algae (laminarin and fucoidans) are the watersoluble compounds [232]. Chen et al. [233] reported the use of microwave-assisted method to obtain polysaccharides from solanum nigrum. Navarro et al. [234] produced 3,6-anhydrogalactose units from galactose 6-sulfated residues of red seaweed galactans utilizing microwave irradiation to carry out the alkaline modification. The experiments were carried out in a domestic microwave oven heating the samples for $1 \mathrm{~min}$ at $1200 \mathrm{~W}$ using Teflon closed-vessels. Furthermore, Yang et al. [235] and RodriguezJasso et al. [231], respectively evaluated the hydrothermal extraction of sulfated polysaccharides of Undaria pinnatifida and Fucus vesiculosus using a digestion microwave oven with a maximum delivered power of $630 \mathrm{~W}$ (at $172{ }^{\circ} \mathrm{C}$ ). Results showed that microwave heating around 30-60 s was more effective in improving polymer dissolution without a noticeable structural degradation. A preliminary development of a microwave prototype at industrial scale was reported by Uy et al. [236]. Carrageenan 
extraction of Eucheumacottonii and Eucheumaspinosum was carried out using an industrial single-mode cavity continuous microwave, at $38 \%$ of full power $(800 \mathrm{~W})$ and with a residence time of $30 \mathrm{~min}$. Since these hydrocolloids are not water soluble, hydrothermal processing extraction was tested with aqueous mixtures of organic solvents. The extracted carrageenans showed high purity, without the need for further purification procedures. González-López et al. [237], produced compounds with antioxidant activity using non-isothermal autohydrolysis process and Sargassum muticum as raw material. In a recent works, Anastyuk et al. [238,239] used autohydrolysis as an alternative strategy for fucoidan depolymerization from brown algae Silvetia babingtonii and Fucus evanescens. The term autohydrolysis is referred to the acid polysaccharide hydrolysis under very mild conditions using $\mathrm{SO}_{3} \mathrm{H}$ groups as source of catalyst in substrate reaction. Rodríguez-Jasso et al. [240] reported the extraction of sulfated polysaccharides by autohydrolysis from Fucus vesiculosus. The results showed that the $\mathrm{pH}$ decrease in the reaction media at high temperatures and times, possibly due to the polysaccharides hydrolysis using the "in situ" $-\mathrm{SO}_{3} \mathrm{H}$ groups as source of catalyst.

\subsection{Hydrothermal processing in microalgae}

Microalgae are an especially promising feedstock for advanced biofuels production for a number of compelling reasons, including high photosynthetic efficiency, higher area-specific yield, possibility of a frequent harvest because of their rapid growth rate and possibility of integration with fossil-fuel-fired power plants to recycle $\mathrm{CO}_{2}$, via photosynthesis. They can also be cultivated in different climates, in saline/brackish water and on non-arable land so there is no competition with conventional cropland. Its cultivation can be coupled with wastewater bioremediation since they can also remove nitrogen, phosphorus and heavy metals [241]. The conventional approach for making biodiesel from microalgae involves the extraction of triglycerides from the microalgal biomass and its subsequent conversion (e.g., via transesterification) into biodiesel fuel. This approach requires dewatering of the microalgae, drying of the dewatered biomass paste, and then solvent extraction of the triglycerides from the dried biomass, all these steps representing up to $90 \%$ of the energy needed to synthesize biodiesel from microalgae [242]. Microalgae biomass usually has a high moisture content (80$90 \%$ ), so the drying process requires a large amount of heating energy. The hydrothermal processing is an alternative technology that significantly improves the overall thermal efficiency of the process [243], as the energy consumption required by hydrothermal processing is very low compared to other processes [244]. Hydrothermal processing offers the advantage that lipids can be extracted while wet and upgraded to produce a crude oillike product. Another potential advantage is that the conventional lipid extraction methods only produce oil from the lipid fraction while hydrothermal processing can produce oil also from the carbohydrate and protein fraction (see Fig. 5). This is significant as some microalgae grow faster with lower lipid content and contain significant amounts of carbohydrates and proteins [245]. With higher plants, the chemistry of the process derives primarily from lignin, cellulose and hemicellulose components. In contrast, microalgae are not lignocellulosic in composition, and the chemistry is entirely different, involving proteins, lipids and carbohydrates (generally not cellulose) [246]. Hydrothermal processing of microalgae was first reported by Dote et al. [247] for high lipid forming from Botryococcus braunii. Those authors successfully used hydrothermal processing, catalyzed by sodium carbonate $\left(\mathrm{Na}_{2} \mathrm{CO}_{3}\right)$, at $300{ }^{\circ} \mathrm{C}$ and a pressure of $10 \mathrm{MPa}$ achieving a maximum yield of $64 \mathrm{wt} \%$ of oil with a HHV of $45.9 \mathrm{MJ} / \mathrm{kg}$ and a positive energy balance for the process (output/input ratio of 6.67: (1). The hydrothermal processing of Botryococcus braunii cells (moisture content of 92\%) was also performed by Sawayama et al. [248] at 200,300 and $340{ }^{\circ} \mathrm{C}$ with $5 \mathrm{wt} \%$ or without $\mathrm{Na}_{2} \mathrm{CO}_{3}$. The maximum yield of oil obtained was 64 wt\% (dry basis) at $300{ }^{\circ} \mathrm{C}$ with $\mathrm{Na}_{2} \mathrm{CO}_{3}$ as catalyst. The produced gas consisted mainly of methane and carbon dioxide. Hydrothermal processing of the same microalgae was also studied by Banerjee el al. [249], who obtained oil in a yield of $57-64 \mathrm{wt} \%$ at $300{ }^{\circ} \mathrm{C}$. The oil was equivalent in quality to petroleum oil. Minowa et al. [250] reported an oil yield of about $37 \%$ on organic basis by direct hydrothermal processing at around $300^{\circ} \mathrm{C}, 60 \mathrm{~min}$ and $10 \mathrm{MPa}$ from the low lipid containing microalgae Dunaliella tertiolecta

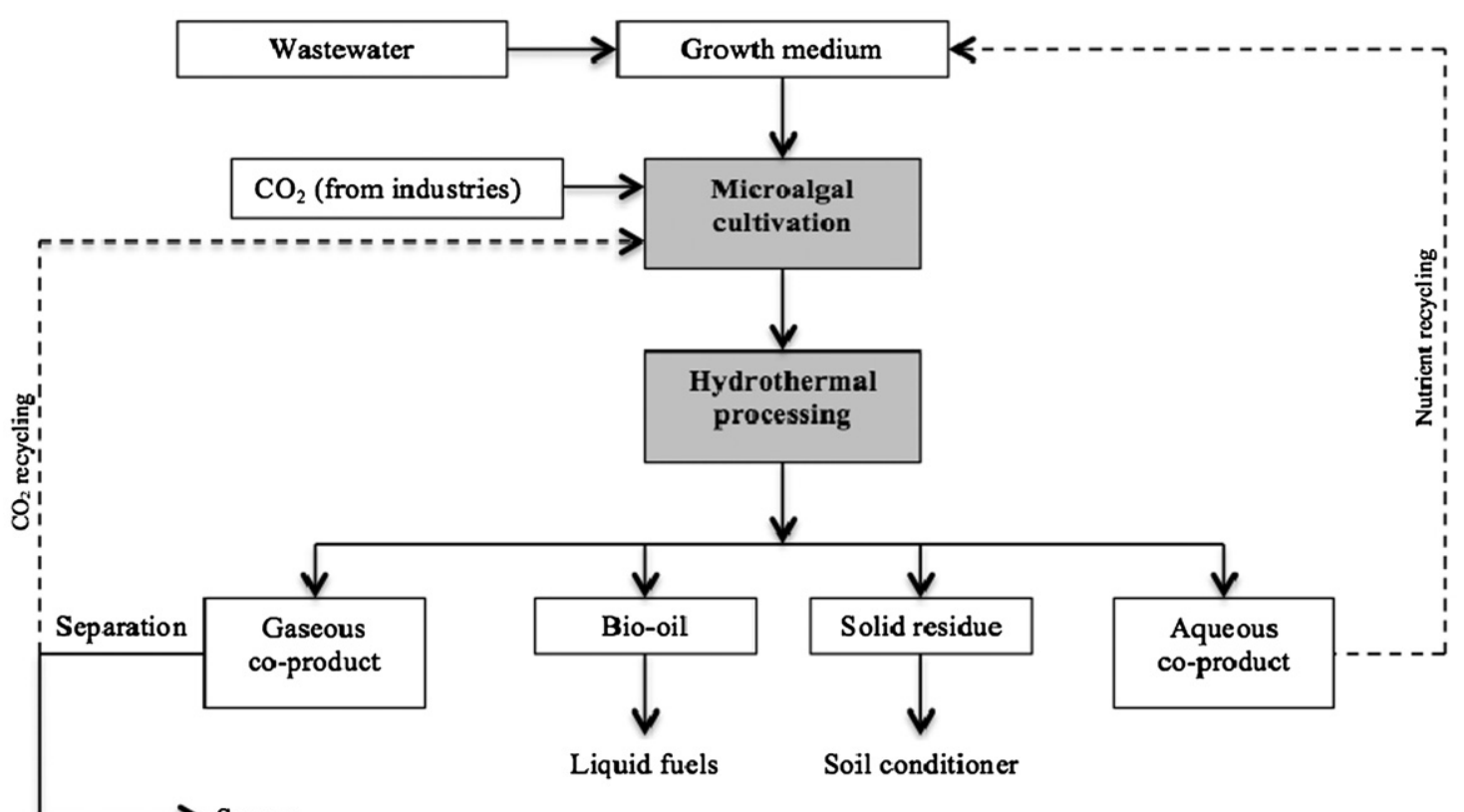

Fig. 5. Conceptual model for microalgal fuel production with hydrothermal processing of biomass conversion into bio-oil. 
(lipid content $20 \mathrm{wt} \%$ ). The oil had HHV of $36 \mathrm{MJ} / \mathrm{kg}$, comparable to those of fuel oil and the process had a positive energy balance of 2.94:1. Other lower lipid containing microalgae such as Spirulina have been liquefied at $350{ }^{\circ} \mathrm{C}, 60 \mathrm{~min}, 5 \mathrm{MPa}$ without catalyst by Matsui et al. [251]. Surprisingly high oil yields were reported (78.3 wt\%) despite the low lipid content, however the oil showed high oxygen content. The most important factors in the hydrothermal processing of microalgae as raw material are temperature, residence time and catalyst dosage. To investigate the influences of these factors on oil yield, Shuping et al. [244] performed the hydrothermal processing of Dunaliella tertiolecta under various temperatures $\left(280-380^{\circ} \mathrm{C}\right)$, residence times $(10-$ $90 \mathrm{~min}$ ), and catalyst dosages (0-10\%). A maximum bio-oil yield of $25.8 \%$ was obtained at a reaction temperature of $360{ }^{\circ} \mathrm{C}$ and a holding time of 50 min using $5 \% \mathrm{Na}_{2} \mathrm{CO}_{3}$ as a catalyst. The results showed that the decomposition of Dunaliella tertiolecta started at a reaction temperature lower than $280{ }^{\circ} \mathrm{C}$, and both conversion and bio-oil yield were strongly dependent on the temperature between 280 and $380{ }^{\circ} \mathrm{C}$. In relation to the residence time, the bio-oil yield appeared to present an initial sharp increase, remaining approximately constant with increasing reaction time beyond $50 \mathrm{~min}$. Also, Yang et al. [252] performed the hydrothermal processing of Microcystis viridis under different conditions of temperature (300 and $340{ }^{\circ} \mathrm{C}$ ), residence time (30 and $60 \mathrm{~min}$ ) and catalyst dosage ( 0 and $5 \%$ of $\mathrm{Na}_{2} \mathrm{CO}_{3}$ ). The initial operational pressure was $3 \mathrm{MPa}$ and the maximum pressure of the autoclave was $10-20 \mathrm{MPa}$. The maximum oil yield was $33 \%$ at the $30 \mathrm{~min}$ holding time, the reaction temperature of $340{ }^{\circ} \mathrm{C}$ and the alkali catalyst dosage of $5 \mathrm{wt} \%$. The HHV of the oil was determined as 28-30 MJ $/ \mathrm{kg}$. Brown et al. [253] converted the microalga Nannochloropsis $s p$. into a crude bio-oil product via hydrothermal processing at different temperatures and a batch holding time of $60 \mathrm{~min}$. A temperature of $350{ }^{\circ} \mathrm{C}$ led to the highest bio-oil yield of $43 \mathrm{wt} \%$. The HHV of the bio-oil was $39 \mathrm{MJ} / \mathrm{kg}$, which is comparable to that of crude petroleum. Alba et al. [254] conducted a study of hydrothermal treatment using the freshwater microalgae Desmodesmus sp., in which a wide range of temperatures $\left(175-450^{\circ} \mathrm{C}\right.$ ) and reaction times (up to $60 \mathrm{~min}$ ), was tested, using a batch reactor system. The maximum oil yield (49 wt\%) was obtained at $375{ }^{\circ} \mathrm{C}$ and $5 \mathrm{~min}$ reaction time, recovering $75 \%$ of the algal calorific value into the oil and an energy densification from 22 to $36 \mathrm{MJ} / \mathrm{kg}$. As presented previously the use of catalyst is one of the factors that should be taken into account in hydrothermal processing of microalgae. Several studies on hydrothermal processing of microalgae were carried out using different catalysts, mainly $\mathrm{Na}_{2} \mathrm{CO}_{3}(208,209,210,213)$. Ross et al. [224] studied the influence of the catalyst type in hydrothermal processing using Chlorella vulgaris and Spirulina as raw material. Catalysts employed include the alkalis, potassium hydroxide and sodium carbonate and the organic acids acetic acid and formic acid. The yields of bio-crude were higher in the presence of organic acids compared to alkali catalysts. Biller et al. [245] investigated three catalysts: an alumina-supported Co/Mo catalyst, an alumina-supported Ni catalyst and an alumina supported Pt catalyst. The results indicate that the bio-crude yields from the hydrothermal processing of Chlorella vulgaris and Nannochloropsis occulta were increased slightly with the use of heterogeneous catalysts but the HHV and the level of de-oxygenation increased up to $10 \%$. Duan and Savage [255] produced crude bio-oils from the microalga Nannochloropsis sp. via reactions in liquid water at $350{ }^{\circ} \mathrm{C}$ and $60 \mathrm{~min}$ in the presence of six different heterogeneous catalysts $\left(\mathrm{Pd} / \mathrm{C}, \mathrm{Pt} / \mathrm{C}, \mathrm{Ru} / \mathrm{C}, \mathrm{Ni} / \mathrm{SiO}_{2}-\mathrm{Al}_{2} \mathrm{O}_{3}, \mathrm{CoMo} / \gamma-\mathrm{Al}_{2} \mathrm{O}_{3}\right.$ (sulfided), and zeolite). Jena et al. [256] used $\mathrm{NiO}$ to assist in the hydrothermal processing of both single (Spirulina) and mixed algae (from open ponds with wastewater) cultures at $350{ }^{\circ} \mathrm{C}$. Interestingly, the added $\mathrm{NiO}$ decreased oil yields. Duan and
Savage [255] refer that the use of a catalyst in hydrothermal processing may be a way to produce a crude hydrocarbon bio-oil directly from wet microalgae in a single processing step. Yeh et al. [257] present an overview of catalysts used in hydrothermal processing of algae and model compounds. Microalgae generally consist of carbohydrates, proteins and lipids. In order to understand the influence of biochemical content of microalgae on hydrothermal processing yields and product distribution, Biller and Ross [226] performed hydrothermal processing on four different microalgae species (Chlorella vulgaris, Nannochloropsis occulata, Porphyridium cruentum and Spirulina) and model biochemical compounds at $350{ }^{\circ} \mathrm{C}, 20 \mathrm{MPa}$ and $60 \mathrm{~min}$. The yields and product distribution obtained for each model compound have been used to predict the behavior of microalgae with different biochemical composition. Model validation using microalgae showed a broad agreement between predicted yields (using Eq. (16)) and actual yields for the different microalgae.

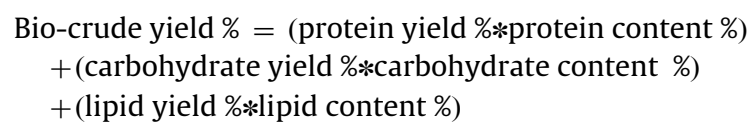

The results showed that yields of bio-crude were 5-25 wt\% higher than the lipid content of the algae depending upon biochemical composition. The yields of bio-crude follow the trend lipids $>$ proteins $>$ carbohydrates. Both proteins and lipids were more efficiently converted to oil without the use of catalysts while carbohydrates were better processed using $\mathrm{Na}_{2} \mathrm{CO}_{3}$. In water, the carbohydrate fraction of microalgae was converted to bio-crude oil with an efficiency of $5-10 \%$ only, and for the proteins the efficiency was around 20\% [226]. The higher the amounts of lipids in the substrate, the higher the biomass yields. This was explained by the high thermal stability of fatty acids. Also, in Sawayama et al. [258] the energy balance of hydrothermal liquefaction of Botryococcus braunii and Dunaliella tertiolecta suggests that the higher lipid content microalgae Botryococcus braunii performed more favorably than the lower lipid microalgae Dunaliella tertiolecta. The hydrothermal processing of $100 \mathrm{~g}$ of dry microalgae results in approximately, $40 \%$ oil and $429.80 \%$ of an aqueous co-product [256]. The water phase resulting from the process concentrates trace mineral matter and nitrogen, phosphorus, potassium (NPK) and may represent a route for recycling of nutrients [224]. Based on this information, Jena et al. [256] evaluated its potential as a nutrient source for cultivation of microalgae Chlorella minutissima. Microalgal growth medium developed by using this aqueous co-product as a nutrient additive to deionized water at $0.2 \% \mathrm{v} / \mathrm{v}$ concentration resulted in the best growth $(0.52 \mathrm{~g} / \mathrm{L})$ for Chlorella minutissima. This study established the proof of concept for combining microalgae cultivation with hydrothermal processing for nutrient recycling. Apart from studies conducted with the purpose of producing biodiesel, there are few studies on the application of hydrothermal processing in microalgae. One of the exceptions is the application of hydrothermal processing in microalgae to create a char product. Employing relatively moderate conditions of temperature $\left(203{ }^{\circ} \mathrm{C}\right)$, residence time $(2 \mathrm{~h})$ and pressure $(1.65 \mathrm{MPa})$, Heilmann et al. [246] converted Chlamydomonas reinhardtii in an energy efficient manner into an algal char product of unique composition and with energy contents in the bituminous coal range. Potential uses for the product include creation of synthesis gas and conversion into industrial chemicals and gasoline, application as a soil nutrient amendment and as a carbon neutral supplement to natural coal for generation of electrical power. No catalytic agents were identified by Heilmann et al. [246] that significantly accelerated carbonization and/or enhanced yield with algal substrates. Shen et al. [259] used Spirulina for the production of acetic acid under hydrothermal processing conditions at $300{ }^{\circ} \mathrm{C}, 17 \mathrm{MPa}$ for 
$80 \mathrm{~s}$ with $\mathrm{H}_{2} \mathrm{O}_{2}$ oxidant. Results showed that acetic acid was obtained with a good yield of $14.9 \%$ on a carbon base proving that it is possible to develop a process for conversion of microalgae biomass into acetic acid.

\section{Conclusions}

The conversion of biomass into chemicals and energy is essential in order to sustain our present and future. In general, hydrothermal processing used in LCMs is the most promising technology that can be conceived as a first step to the fractionation and obtention of products with high added-value according to the biorefinery concept. Depending on the operational conditions (temperature, residence time, particle size, moisture and reactor configuration), hydrothermal processing can cause several effects including hemicellulose depolymerization (oligomers, monomers), alteration/degradation of lignin (phenolic compounds) and increased availability of cellulose. Owing to these effects, the products obtained are a valuable source of materials for the chemical, pharmaceutical, food and energy industries. Moreover, the use of hydrothermal processing in aquatic biomass (macro- and micro-algae) has been shown to be an interesting technology for the production of bio-crude oil and extraction of polysaccharides for different applications and hydrolysis into sugars for a further utilization in processes such as fermentation.

\section{Acknowledgements}

The authors Héctor A. Ruiz and Bruno D. Fernandes thank to the Portuguese Foundation for Science and Technology (FCT, Portugal) for their fellowships (grant number: SFRH/BPD/77361/ 2011 and SFRH/BD/44724/2008, respectively) and Rosa M. Rodríguez-Jasso thanks to MexicanScience and Technology Council (CONACYT, Mexico) for PhD fellowship support (grant number: 206607/230415).

\section{References}

[1] Elliot DC. Biomass, chemicals from. In: Cleveland CJ, editor. Encyclopedia of energy. Oxford, United Kingdom: Elsevier, Inc; 2004. p. 163-74.

[2] Octave S, Thomas D. Biorefinery: toward an industrial metabolism. Biochemie 2009;91:659-64.

[3] Cherubini F, Ulgiati S. Crop residues as raw materials for biorefinery systems- A LCA case study. Applied Energy 2010;87:47-57.

[4] Pronyk C, Mazza G, Tamaki Y. Production of carbohydrates, lignins, and minor components from triticale straw by hydrothermal treatment. Journal of Agricultural and Food Chemistry 2011;59:3788-96.

[5] Roesijadi G, Jones SB, Snowden-Swan LJ, Zhu Y. Macroalgae as a biomass feedstock: a preliminary analysis. Richland Washington, USA: Pacific Northwest National Laboratory (PNNL); 2010.

[6] Chisti Y. Biodiesel from microalgae. Biotechnology Advances 2007;25: 294-306.

[7] Bobleter O, Niesner R, Röhr M. The hydrothermal degradation of cellulosic matter to sugars and their fermentative conversion to protein. Journal of Applied Polymer Science 1976;20:2083-93.

[8] Ruiz HA, Ruzene DS, Silva DP, Macieira da Silva FF, Vicente AA, Teixeira JA. Development and characterization of an environmentally friendly process sequence (autohydrolysis and organosolv) for wheat straw delignification. Applied Biochemistry and Biotechnology 2011;164:629-41.

[9] Romaní A, Garrote G, López F, Parajó JC. Eucalyptus globulus wood fractionation by autohydrolysis and organosolv delignification. Bioresource Technology 2011;102:5896-904.

[10] Feria MJ, López F, García JC, Pérez A, Zamudio MAM, Alfaro A. Valorization of Leucaena leucocephala for energy and chemicals from autohydrolysis. Biomass \& Bioenergy 2011;35:2224-33.

[11] Romaní A, Garrote G, Parajó JC. Bioethanol production from autohydrolyzed Eucalyptus globulus by Simultaneous Saccharification and Fermentation operating at high solids loading. Fuel 2012;94:305-12.

[12] Ruiz HA, Ruzene DS, Silva DP, Quintas MAC, Vicente AA, Teixeira JA Evaluation of a hydrothermal process for pretreatment of wheat straweffect of particle size and process conditions. Journal of Chemical Technology \& Biotechnology 2011;86:88-94.
[13] Díaz MJ, Cara C, Ruiz E, Romero I, Moya M, Castro E. Hydrothermal pretreatment of rapessed straw. Bioresource Technology 2010;101:2428-35.

[14] Petersen MØ, Larsen J, Thomsen MH. Optimization of hydrothermal pretreatment of wheat straw for production of bioethanol at low water consumption without addition of chemicals. Biomass \& Bioenergy 2009;33:834-40.

[15] Chaogang L, Wyman CE. Partial flow of compressed-hot water through corn stover to enhance hemicellulose sugar recovery and enzymatic digestibility of cellulose. Bioresource Technology 2005;96:1978-85.

[16] $\mathrm{Yu} \mathrm{Y}, \mathrm{Wu} \mathrm{H}$. Understanding the primary liquid products of cellulose hydrolysis in hot-compressed water at various reaction temperatures. Energy Fuels 2010;24:1963-71.

[17] Suryawati L, Wilkins MR, Bellmer DD, Huhnke RL, Maness NO, Banat IM. Effect of hydrothermolysis process conditions on pretreated switchgrass composition and ethanol yield by SSF with Kluyveromyces marxianus IMB4. Process Biochemistry 2009;44:540-5.

[18] Faga BA, Wilkins MR, Banat IM. Ethanol production through simultaneous saccharification and fermentation of switchgrass using Saccharomyces cerevisiae $\mathrm{D}_{5} \mathrm{~A}$ and thermotolerant Kluyveromyces marxianus IMB. Bioresource Technology 2010;101:2273-9.

[19] Pérez JA, Ballesteros I, Ballesteros M, Sáez F, Negro MJ, Manzanares P. Optimizing liquid hot water pretreatment conditions to enhance sugar recovery from wheat straw for fuel-ethanol production. Fuel 2008;87:3640-7.

[20] Kim Y, Mosier NS. Enzymatic digestion of liquid hot water pretreated hybrid poplar. Biotechnology Progress 2009;25:340-8.

[21] Ingram T, Wörmeyer K, Lima JCI, Bockemuhl V, Antranikian G, Brunner G, et al. Comparison of different pretreatment methods for lignocellulosic materials. Part I: Conversion of rye straw to valuable products. Bioresource Technology 2011;102:5221-8.

[22] Garrote G, Cruz JM, Domínguez H, Parajó JC. Non-isothermal autohydrolysis of barley husks: product distribution and antioxidant activity of ethyl acetate soluble fractions. Journal of Food Engineering 2008;84:544-52.

[23] Weil J, Sarikaya A, Rau S, Goetz J, Ladisch C, Brewer M, et al. Pretreatment of yellow poplar sawdust by pressure cooking in water. Applied Biochemistry and Biotechnology 1997;68:21-40.

[24] Bobleter O. Hydrothermal degradation and fractionation of saccharides and polysaccharides. In: Dumitriu S, editor. Polysaccharides, structural, diversity and functional versatility. New York: Marcel Dekker; 2005. p. 893-936.

[25] Yu G, Yano S, Inoue H, Inoue S, Endo T, Sawayama S. Pretreatment of rice straw by a hot-compressed water process for enzymatic hydrolysis. Applied Biochemistry and Biotechnology 2010;160:539-51.

[26] Romaní A, Garrote G, Alonso JL, Parajó JC. Bioethanol production from hydrothermal pretreated Eucalyptus globulus wood. Bioresource Technology 2010;101:8706-12.

[27] Cybulska I, Lei H, Julson J. Hydrothermal pretreatment and enzymatic hydrolysis of prairie cord grass. Energy Fuels 2010;24:718-27.

[28] Garrote G, Domínguez H, Parajó JC. Hydrothermal processing of lignocellulosic materials. Holz Roh Werkst 1999;57:191-202.

[29] Mosier N, Hendrickson R, Ho N, Sedlak M, Ladisch MR. Optimization of pH controlled liquid hot water pretreatment of corn stover. Bioresource Technology 2005;96:1986-93.

[30] Garrote G, Cruz JM, Domínguez H, Parajó JC. Valorisation of waste fractions from autohydrolysis of selected lignocellulosic materials. Journal of Chemical Technology \& Biotechnology 2003;78:392-8.

[31] Zhang YHP, Din SY, Mielenz JR, Cui JB, Elander RT, Laser M, et al. Fractionating recalcitrant lignocellulose at modest reaction conditions. Biotechnology and Bioengineering 2007;97:214-33.

[32] Liu K, Lin X, Yue J, Li X, Fang X, Zhu M, et al. High concentration ethanol production from corncob residues by fed-batch strategy. Bioresource Technology 2010;101:4952-8.

[33] Wang L, Yang M, Fan X, Zhu X, Xu T, Yuan Q. An environmentally friendly and efficient method for xylitol bioconversion with high-temperaturesteaming corncob hydrolysate by adapted Candida tropicalis. Process Biochemistry 2011;46:1619-26.

[34] Weiss ND, Farmer JD, Schell DJ. Impact of corn stover composition on hemicellulose conversion during dilute acid pretreated and enzymatic cellulose digestibility of the pretreated solids. Bioresource Technology 2010;101:674-8.

[35] Liu CZ, Cheng XY. Improved hydrogen production via thermophilic fermentation of corn stover by microwave-assisted acid pretreatment. International Journal of Hydrogen Energy 2010;35:8945-52.

[36] Talebnia F, Karakashev D, Angelidaki I. Production of bioethanol from wheat straw: an overview on pretreatment, hydrolysis and fermentation. Bioresource Technology 2010;101:4744-53.

[37] Hsu TC, Guo GL, Chen WH, Hwang WS. Effect of dilute acid pretreatment of rice straw on structural properties and enzymatic hydrolysis. Bioresource Technology 2010;101:4907-13.

[38] Yadav KS, Naseeruddin S, Prashanthi GS, Sateesh L, Rao LV. Bioethanol fermentation of concentrated rice straw hydrolysate using co-culture of Saccharomyces cerevisiae and Pichia stipites. Bioresource Technology 2011:102:6473-8.

[39] Mesa L, González E, Ruiz E, Romero I, Cara C, Felissia F, et al. Preliminary evaluation of organosolv pre-treatment of sugar cane bagasse for glucose production: application of $2^{3}$ experimental design. Applied Energy 2010;87:109-14. 
[40] Maeda RN, Serpa VI, Rocha VAL, Mesquita RAA, LMMS Anna, de Castro AM, et al. Enzymatic hydrolysis of pretreated sugar cane bagasse using Penicillium funiculosum and Trichoderma harzianum cellulases. Process Biochemistry 2011;46:1196-201.

[41] Sun XF, Jing Z, Fowler P, Wu Y, Rajaratnam. Structural characterization and isolation of lignin and hemicelluloses from barley straw. Industrial Crops and Products 2011;33:588-98.

[42] García-Aparicio MP, Oliva JM, Manzanares P, Ballesteros M, Ballesteros I, González A, et al. Second-generation ethanol production from steam exploded barley straw by Kluyveromyces marxianus CECT 10875, Fuel 2011;90:1624-30.

[43] Garrote G, Falque E, Domínguez H, Parajó JC. Autohydrolysis of agricultural residues: study of reaction byproducts. Bioresource Technology 2007;98: 1951-7.

[44] Abbas A, Ansumali S. Global potential of rice husk as a renewable feedstock for ethanol biofuel production. Bioenergy Research 2010;3:328-34.

[45] Gullón B, Yañez R, Alonso JL, Parajó JC. Production of oligosaccharides and sugar from rye straw: a kinetic approach. Bioresource Technology 2010;101:6676-84

[46] Lu X, Zhang Y, Angelidaki I. Optimization of $\mathrm{H}_{2} \mathrm{SO}_{4}$-catalyzed hydrothermal pretreatment of rapeseed straw for bioconversion to ethanol: focusing on pretreatment at high solids content. Bioresource Technology 2009;100:3048-53.

[47] Ruiz E, Cara C, Manzanares P, Ballesteros M, Castro E. Evaluation of steam explosion pre-treatment fro enzymatic hydrolysis of sunflower stalks. Enzyme and Microbial Technology 2008;42:160-6.

[48] Caparrós S, Ariza J, López F, Nacimiento JA, Garrote G, Jiménez L. Hydrothermal treatment and ethanol pulping of sunflower stalks. Bioresource Technology 2008;99:1368-72.

[49] Zhang J, Ma X, Yu J, Zhang X, Tan T. The effects of four different pretreatments on enzymatic hydrolysis of sweet sorghum bagasse. Bioresource Technology 2011;102:4585-9.

[50] Goshadrou A, Karimi K, Taherzadeh MJ. Bioethanol production from sweet sorghum bagasse by Mucor hiemalis. Industrial Crops and Products 2011;34:1219-25.

[51] Keshwani DR, Cheng JJ. Switchgrass for bioethanol and other value-added applications. A review. Bioresource Technology 2009;100:1515-23.

[52] Hu Z, Foston M, Ragauskas AJ. Comparative studies on hydrothermal pretreatment and enzymatic saccharification of leaves and internodes of alamo switchgrass. Bioresource Technology 2011;14:7224-8.

[53] Ai J, Tschirner U. Fiber length and pulping characteristics of switchgrass, alfalfa stems, hybrid poplar and willow biomasses. Bioresource Technology 2010;101:215-21.

[54] Wang Z, Keshwani DR, Redding AP, Cheng JJ. Sodium hydroxide pretreatment and enzymatic hydrolysis of coastal Bermuda grass. Bioresource Technology 2010;101:3583-5.

[55] Tian S, Zhu W, Gleisner R, Pan XJ, Zhu JY. Comparisons of SPORL and dilute acid pretreatments for sugar and ethanol productions from aspen. Biotechnology Progress 2011;27:419-27.

[56] Pan X, Gilkes N, Kadla J, Pye K, Saka S, Gregg D, et al. Bioconversion of Hybrid poplar to ethanol and co-products using an organosolv fractionation process: optimization of process yields. Biotechnology and Bioengineering 2006;94:851-61.

[57] Gonzalez R, Treasure T, Phillips R, Jameel H, Saloni D, Abt R, et al. Converting Eucalyptus biomass into ethanol: financial and sensitivity analysis in a co-current dilute acid process. Part II. Biomass \& Bioenergy 2011;35:767-72.

[58] Araque E, Parra C, Freer J, Contreras D, Rodríguez J, Mendonça R, et al. Evaluation of organosolv pretreatment for conversion of Pinus radiata D don to ethanol. Enzyme and Microbial Technology 2008;43:214-9.

[59] Shafiei M, Karimi K, Taherzadeh MJ. Pretreatment of spruce and oak by $N$ methylmorpholine- $\mathrm{N}$-oxide (NMMO) for efficient conversion of their cellulose to ethanol. Bioresource Technology 2010;101:4914-8.

[60] Lee DH, Cho EY, Kim CJ, Kim SB. Pretreatment of waste newspaper using ethylene glycol for bioethanol production. Biotechnology and Bioprocess Engineering 2010;15:1094-101.

[61] Peng L, Chen Y. Conversion of paper sludge to ethanol by separate hydrolysis and fermentation (SHF) using Saccharomyces cerevisiae. Biomass \& Bioenergy 2011;35:1600-6.

[62] Kim Y, Hendrickson R, Mosier NS, Ladisch MR, Bals B, Balan V, et al. Effect of compositional variability of distiller's grains on cellulosic ethanol production. Bioresource Technology 2010;101:5385-93.

[63] Carvalheiro F, Garrote G, Parajó JC, Pereira H, Gírio FM. Kinetic modeling of brewery's spent grain autohydrolysis. Biotechnology Progress 2005;21:233-43.

[64] Pires EJ, Ruiz HA, Teixeira JA, Vicente AA. A New approach on brewer's spent grains treatment and potential use as lignocellulosic yeast cells carriers. Journal of Agricultural and Food Chemistry 2012;60:5994-9.

[65] Griebl A, Lange T, Weber H, Milacher W, Sixta H. Xylo-oligosaccharide (XOS) formation through hydrothermolysis of xylan derived from viscose process. Macromolecular Symposia 2006;232:107-20.

[66] Gullón P, Conde E, Moure A, Domínguez H, Parajó JC. Selected process alternatives for biomass refining. A review. The Open Agriculture Journal 2010;4:135-44.

[67] Gírio FM, Fonseca C, Carvalheiro F, Duarte LC, Marques S, Bogel-Lukasik R. Hemicellulose for fuel ethanol: a review. Bioresource Technology 2010;101:4775-800.
[68] Vila C, Romero J, Francisco JL, Garrote G, Parajó JC. Extracting value from Eucalyptus wood before kraft pulping: effects of hemicelluloses solubilization on pulp properties. Bioresource Technology 2011;102:5251-4.

[69] Ruiz HA, Silva DP, Ruzene DS, Lima LF, Vicente AA, Teixeira JA. Bioethanol production from hydrothermal pretreated wheat straw by a flocculating Saccharomyces cerevisiae strain-effect of process conditions. Fuel 2012;95:528-36.

[70] Michelin M, de Lourdes M, Polizeli TM, Ruzene DS, Silva DP, Ruiz HA, et al Production of xylanase and $\beta$-xylosidase from autohydrolysis liquor of corncob using two fungal strains. Bioprocess and Biosystems Engineering 2012;35:1185-92.

[71] Ruiz HA, Cerqueira MA, Silva HD, Rodríguez-Jasso RM, Vicente AA, Teixeira JA. Biorefinery valorization of autohydrolysis wheat straw hemicellulose to be applied in a polymer-blend film. Carbohydrate Polymers 2013;92: 2154-62.

[72] He W, Li G, Kong L, Wang $\mathrm{H}$, Huang J, Xu J. Application of hydrothermal reaction in resource recovery of organic wastes. Resources, Conservation and Recycling 2008;52:691-9.

[73] Peterson AA, Vogel F, Lachance RP, Froling M, Antal Jr MJ, Tester JW. Thermochemical biofuel production in hydrothermal media: a review of sub- and supercritical water technologies. Energy \& Environmental Science 2008;1:32-65.

[74] Loppinet-Serani A, Aymonier C, Cansell F. Supercritical water for environmental technologies. Journal of Chemical Technology \& Biotechnology 2010;85:583-9.

[75] Möller M, Nilges P, Harnisch F, Schröder U. Subcritical water as reaction environment: fundamentals of hydrothermal biomass transformation. ChemSusChem 2011;4:566-79.

[76] Liu S. Woody biomass: niche position as a source of sustainable renewable chemicals and energy and kinetics of hot-water extraction/hydrolysis. Biotechnology Advances 2010;28:563-82.

[77] Ballesteros I, Oliva JM, Negro MJ, Manzanares P, Ballesteros M. Enzymatic hydrolysis of steam exploded herbaceous agricultural waste (Brassica carinata) at different particle sizes. Process Biochemistry 2002;38:187-92.

[78] Duff SJB, Murray WD. Bioconversion of forest products industry waste cellulosics to fuel ethanol: a review. Bioresource Technology 1996;55:1-33.

[79] Kálmán G, Varga E, Réczey K. Dilute sulphuric acid pretreatment of corn stover at long residence times. Chemical and Biochemical Engineering Quarterly 2002;16:151-7.

[80] Karaö S, Bhaskar T, Muto A, Sakata Y, Uddin MA. Low temperature hydrothermal treatment of biomass effect of reaction parameters on products and boiling point distributions. Energy \& Fuels 2004;18:234-41.

[81] Brownell HH, Yu EKC, Saddler JN. Steam-explosion pretreatment of wood: effect of chip size, acid, moisture content and pressure drop. Biotechnology and Bioengineering 1986;28:792-801.

[82] Mosier N, Wyman C, Dale B, Elander R, Lee YY, Holtzapple M, et al. Features of promising technologies for pretreatment of lignocellulosic biomass. Bioresource Technology 2005;96:673-86.

[83] Ballesteros I, Oliva JM, Navarro AA, González A, Carrasco J, Ballesteros M. Effect of chip size on steam explosion pretreatment of softwood. Applied Biochemistry and Biotechnology 2000;84-86 97-10.

[84] Hosseini SA, Shah N. Multiscale modelling of hydrothermal biomass pretreatment for chip size optimization. Bioresource Technology 2009; 100:2621-8.

[85] Cullis IF, Saddler JN, Mansfield SD. Effect of initial moisture content and chip size on the bioconversion efficiency of softwood lignocellulosics. Biotechnology and Bioengineering 2004;85:413-21.

[86] Rodríguez A, Moral A, Sánchez R, Requejo A, Jiménez L. Influence of variables in the hydrothermal treatment of rice straw on the composition of the resulting fractions. Bioresource Technology 2009;100:4863-6.

[87] Weil S, Brewer M, Hendrickson R, Sarikaya A, Ladish MR. Continuous pH monitoring during pretreatment of yellow poplar wood sawdust by pressure cooking in water. Applied Biochemistry and Biotechnology 1998;70-72:99-111.

[88] Mosier NS, Hendrickson R, Brewer M, Ho N, Sedlak M, Dreshel R, et al Industrial scale-up of $\mathrm{pH}$-controlled liquid hot water pretreatment of corn fiber for fuel ethanol production. Applied Biochemistry and Biotechnology 2005;125:77-97.

[89] Cara C, Romero I, Oliva JM, Sáez F, Castro E. Liquid hot water pretreatment of olive tree pruning residues. Applied Biochemistry and Biotechnology 2007;136-140:379-94.

[90] Martínez M, Gullón B, Yáñez R, Alonso JL, Parajó JC. Kinetic assessment on the autohydrolysis of pectin-rich by-products. Chemical Engineering Journal 2010;162:480-6.

[91] Hansen MAT, Kristensen JB, Felby C, Jørgensen H. Pretreatment and enzymatic hydrolysis of wheat straw (Triticum aestivum L.)-The impact of lignin relocation and plant tissues on enzymatic accessibility. Bioresource Technology 2011;102:2804-11.

[92] Boussarsar H, Rogé B, Mathlouthi M. Optimization of sugarcane bagasse conversion by hydrothermal treatment for the recovery of xylose. Bioresource Technology 2009;100:6537-42.

[93] Archambault-Leger V, Shao X, Lynd LR. Integrated analysis of hydrothermal flow through pretreatment. Biotechnology for Biofuels 2012;5:49.

[94] Phaiboonsilpa N, Tamunaidu P, Saka S. Two-step hydrolysis of nipa (Nypa fruticans) frond as treated by semi-flow hot-compressed water. Holzforschung 2011;65:659-66. 
[95] Liu C, Wyman CE. Partial flow of compressed-hot water through corn stover to enhance hemicellulose sugar recovery and enzymatic digestibility of cellulose. Bioresource Technology 2005;96:1978-85.

[96] Ingram T, Rogalinski T, Bockemühl V, Antranikian G, Brunner G. Semicontinuous liquid hot water pretreatment of rye straw. The Journal of Supercritical Fluids 2009;48:238-46.

[97] Yu Y, Wu H. Characteristics and precipitation of glucose oligomers in the fresh liquid products obtained from the hydrolysis of cellulose in hotcompressed water. Industrial \& Engineering Chemistry Research 2009;48: 10682-90.

[98] Pronyk C, Mazza G. Kinetic modeling of hemicellulose hydrolysis from triticale straw in a pressurized low polarity water flow-through reactor. Industrial \& Engineering Chemistry Research 2010;49:6367-75.

[99] Liu C, Wyman CE. Impact of fluid velocity on hot water only pretreatment of corn stover in a flowthrough reactor. Applied Biochemistry and Biotechnology 2004;113-116:977-87.

[100] Rogalinski T, Ingram T, Brunner G. Hydrolysis of lignocellulosic biomass in water under elevated temperatures and pressures. The Journal of Supercritical Fluids 2008;47:54-63.

[101] Saito T, Sasaki M, Kawanabe H, Yoshino Y, Goto M. Susbcritical water reaction behavior of $\mathrm{D}$-glucose as a model compound for biomass using two different continuous-flow reactor configurations. Chemical Engineering \& Technology 2009;32:527-33.

[102] Kumar S, Gupta R, Lee YY, Gupta RB. Cellulose pretreatment in subcritical water: effect of temperature on molecular structure and enzymatic reactivity. Bioresource Technology 2010;101:1337-47.

[103] Makishima S, Mizuno M, Sato N, Shinji K, Suzuki M, Nozaki K, et al. Development of continuous flow type hydrothermal reactor for hemicellulose fraction from corncob. Bioresource Technology 2009;100:2842-8.

[104] Romaní A, Garrote G, Alonso JL, Parajó JC. Experimental assessment on the enzymatic hydrolysis of hydrothermal pretreated eucalyptus globulus wood. Industrial \& Engineering Chemistry Research 2010;49:4653-63.

[105] Overend RP, Chornet E. Fractionation of lignocellulosic by steam-aqueous pretreatments. Philosophical Transactions of the Royal Society of London 1987;321:523-36.

[106] Chornet E, Overend RP. Phenomenological kinetics and reaction engineering aspects of steam/aqueous treatments. In: Focher B, Marzetti A, Crescenzi V, editors. Steam explosion techniques: fundamentals and industrial applications. New York: Goran and Breach Science Publishers; 1991. p. 21-58.

[107] Yanagida T, Fujimoto S, Minowa T. Application of the severity parameter for predicting viscosity during hydrothermal processing of dewatered sewage sludge for a commercial PFBC plant. Bioresource Technology 2010;101:2034-45.

[108] Simpson WT. Estimating heating times of wood boards, square timbers, and logs in saturated steam by multiple regression. Forest Products Journal 2006;56:26-8

[109] Hosseini SA, Lambert R, Kucherenko A, Shah N. Multiscale modeling of hydrothermal pretreatment: from hemicellulose hydrolysis to biomass size optimization. Energy Fuels 2010;24:4673-80.

[110] Pedersen M, Meyer AS. Lignocellulose pretreatment severity-relating $\mathrm{pH}$ to biomatrix opening. New Biotechnology 2010;27:739-50.

[111] Jacquet N, Quiévy N, Vanderghem C, Janas S, Blecker C, Wathelet B, et al. Influence of steam explosion on the thermal stability of cellulose fibres. Polymer Degradation and Stability 2011;96:1582-8.

[112] Aguedo M, Vanderghem C, Goffin D, Richel A, Paquot M. Fast and high yield recovery of arabinose from destarched wheat bran. Industrial Crops and Products 2013;43:318-25.

[113] Garrote G, Domínguez H, Parajó JC. Mild autohydrolysis: an environmentally friendly technology for xylooligosaccharides production from wood Journal of Chemical Technology \& Biotechnology 1999;74:1101-9.

[114] Garrote G, Domínguez H, Parajó JC. Kinetic modelling of corncob autohydrolysis. Process Biochemistry 2001;36:571-8.

[115] Garrote G, Domínguez H, Parajó JC. Autohydrolysis of corncob: study of non-isothermal operation for xylooligosaccharides production. Journal of Food Engineering 2002;52:211-8.

[116] Nabarlatz D, Farriol X, Montané D. Kinetic modeling of the autohydrolysis of lignocellulosic biomass for the production of hemicellulose-derived oligosaccharides. Industrial \& Engineering Chemistry Research 2004;43:4124-31.

[117] Zhuang X, Yuan Z, Ma L, Wu C, Xu M, Xu J, et al. Kinetic study of hydrolysis of xylan and agricultural wastes with hot liquid water. Biotechnology Advances 2009;27:578-82.

[118] Martínez M, Gullón B, Yañez R, Alonso JL, Parajó JC. Kinetic assessment on the autohydrolysis of pectin-rich by-products. Chemical Engineering Journal 2010;162:480-6.

[119] Zhao Y, Lu WJ, Wang HT. Supercritical hydrolysis of cellulose for oligosaccharide production in combined technology. Chemical Engineering Journal 2009;150:411-7.

[120] Xu J, Thomsen MH, Thomsen AB. Ethanol production from hydrothermal pretreated corn stover with a loop reactor. Biomass \& Bioenergy 2010;34:334-9.

[121] Walsum GPV, Allen SG, Spencer MJ, Laser MS, Antal Jr MJ, Lynd LR. Conversion of lignocellulosics pretreated with liquid hot water to ethanol. Applied Biochemistry and Biotechnology 1996;57-58:157-70.

[122] Pérez JA, González A, Oliva JM, Ballesteros I, Manzanares P. Effect of process variables on liquid hot water pretreatment of wheat straw for bioconversion to fuel-ethanol in a batch reactor. Journal of Chemical Technology \& Biotechnology 2007;82:929-38.
[123] Negro MJ, Manzanares P, Ballesteros I, Oliva JM, Cabañas A, Ballesteros M. Hydrothermal pretreatment conditions to enhance ethanol production from poplar biomass. Applied Biochemistry and Biotechnology 2003;105108:87-100.

[124] Rohowsky B, Häßler T, Gladis A, Remmele E, Schieder D, Faulstich M Feasibility of simultaneous saccharification and juice co-fermentation on hydrothermal pretreated sweet sorghum bagasse for ethanol production. Applied Energy 2013;102:211-19.

[125] Brandon SK, Sharma KN, Hawkins GM, Anderson WF, Chambliss CK, DoranPeterson J. Ethanol and co-product generation from pressurized batch hot water pretreated T85 bermudagrass and Merkeron napiergrass using recombinant Escherichia coli as biocatalyst. Biomass \& Bioenergy 2011;35:3667-73.

[126] Ares-Peón IA, Romaní A, Garrote G, Parajó JC. Invasive biomass valorization: environmentally friendly processes for obtaining second generation bioethanol and saccharides from Ulex europæus. Journal of Chemical Technology \& Biotechnology (In press); http://dx.doi.org/10.1002/jctb.3963.

[127] Kristensen JB, Thygesen LG, Felby C, Jørgensen H, Elder T. Cell-wall structural changes in wheat straw pretreated for bioethanol production. Biotechnology for Biofuels 2008:1-5.

[128] Zhang T, Wyman CE, Jakob K, Yang B. Rapid selection and identification of Miscanthus genotypes with enhanced glucan and xylan yields from hydrothermal pretreatment followed by enzymatic hydrolysis. Biotechnology for Biofuels 2012;5:56.

[129] Cannella D, Hsieh CC, Felby C, Jørgensen H. Production and effect of aldonic acids during enzymatic hydrolysis of lignocellulose at high dry matter content. Biotechnology for Biofuels 2012;5:26.

[130] Requejo A, Peleteiro S, Rodríguez A, Garrote G, Parajó JC. Valorization of residual woody biomass (Olea europaea trimmings) based on aqueous fractionation. Journal of Chemical Technology \& Biotechnology 2012;87: 87-94.

[131] Hideno A, Inoue $H$, Yanagida $T$, Tsukahara K, Endo $T$, Sawayama S. Combination of hot compressed water treatment and wet disk milling for high sugar recovery yield in enzymatic hydrolysis of rice straw. Bioresource Technology 2012;104:743-8.

[132] Wang W Yuan T, Wang K, Cui B, Dai Y. Statistical optimization of cellulase production by the brown rot fungi, Fomitopsis palustris, and its application in the enzymatic hydrolysis of LHW-pretreated woody biomass. Process Biochemistry 2012;47:2552-6.

[133] Menon V, Rao M. Trends in bioconversion of lignocellulose: biofuels, platform chemicals \& biorefinery concept. Progress in Energy and Combustion Science 2012;38:522-50.

[134] Zhao X, Zhang L, Liu D. Biomass recalcitrance. Part II: Fundamentals of different pre-treatments to increase the enzymatic digestibility of lignocellulose. Biofuels, Bioproducts and Biorefining 2012;6:561-79.

[135] Goh CS, Lee KT, Bhatia S. Hot compresses water pretreatment of oil palm fronds to enhance glucose recovery fro production of second generation bioethanol. Bioresource Technology 2010;101:7362-7.

[136] Lee JM, Shi J, Venditti RA, Jameel H. Autohydrolysis pretreatment of costal Bermuda grass for increased enzyme hydrolysis. Bioresource Technology 2009; 100:6434-41.

[137] Zeng M, Mosier NS, Huang CP, Sherman DM, Ladisch MR. Microscopic examination of changes of plant cell structure in corn stover due to hot water pretreatment and enzymatic hydrolysis. Biotechnology and Bioengineering 2007;2:265-78.

[138] Thomsen MH, Thygesen A, Thomsen AB. Hydrothermal treatment of wheat straw at pilot plant scale using a three-step reactor system aiming at high hemicellulose recovery, high cellulose digestibility and low lignin hydrolysis. Bioresource Technology 2008;99:4221-8.

[139] Hu Z, Ragauskas A. Hydrothermal pretreatment of switchgrass. Industrial \& Engineering Chemistry Research 2011:50:4225-30.

[140] Xiao LP, Sun ZJ, Shi ZJ, Xu F, Sun RC. Impact of hot compressed water pretreatment on the structural changes of woody biomass for bioethanol production. Biology Research 2011;6:1576-98.

[141] Yu Q, Zhuang X, Yuan Z, Wang Q, Qi W, Wang W, et al. Two-step liquid hot water pretreatment of Eucalyptus grandis to enhance sugar recovery and enzymatic digestibility of cellulose. Bioresource Technology 2010;101:4895-9.

[142] Ares-Peón IA, Vila C, Garrote G, Parajó JC. Enzymatic hydrolysis of autohydrolyzed barley husks. Journal of Chemical Technology \& Biotechnology 2011;86:251-60.

[143] Ruiz HA, Vicente AA, Teixeira JA. Kinetic modeling of enzymatic saccharification using wheat straw pretreated under autohydrolysis and organosolv process. Industrial Crops and Products 2012;36:100-7.

[144] Cybulska I, Brudecki G, Rosentrater K, Lei H, Julson J. Catalyzed modified clean fractionation of prairie cordgrass integrated with hydrothermal posttreatment. Biomass \& Bioenergy 2012;46:389-401.

[145] Silva VFN, Arruda PV, Felipe MGA, Gonçalves AR, Rocha GJ. Fermentation of cellulosic hydrolysates obtained by enzymatic saccharification of sugarcane bagasse pretreated by hydrothermal processing. Journal of Industrial Microbiology and Biotechnology 2011;38:809-17.

[146] Thomsen MH, Thygesen A, Jørgensen H, Larsen J, Christensen BH, Thomsen AB. Preliminary results on optimization of pilot scale pretreatment of wheat straw used in coproduction of bioethanol and electricity. Applied Biochemistry and Biotechnology 2006;126-132:448-60. 
[147] Larsen J, Petersen MØ, Thirup L, Li HW, Iversen FK. The IBUS processlignocellulosic bioethanol close to a commercial reality. Chemical Engineering \& Technology 2008;31:765-72.

[148] Gnansounou E. Production and use of lignocellulosic bioethanol in Europe: current situation and perspectives. Bioresource Technology 2010;101: 4842-50.

[149] Modenbach AA, Nokes SE. The use of high-solids loadings in biomass pretreatment-a review. Biotechnology and Bioengineering 2012;109: $1430-42$.

[150] Larsen J, Haven MØ, Thirup L. Inbicon makes lignocellulosic ethanol a commercial reality. Biomass \& Bioenergy 2012;46 36-5.

[151] Treasure T, Gonzalez R, Venditti R, Pu Y, Jameel H, Kelley S, et al. Coproduction of electricity and ethanol, process economics of value prior combustion. Energy Conversion and Management 2012;62:141-53.

[152] Littlewood J, Murphy RJ, Wang L. Importance of policy support and feedstock prices one economic feasibility of bioethanol production from wheat straw in the UK. Renewable \& Sustainable Energy Reviews 2013;17: 291-300.

[153] Sakaki T, Shibata M, Sumi T, Yasuda S. Saccharification of cellulose using a hot-compressed water-flow reactor. Industrial \& Engineering Chemistry Research 2002;41:661-5.

[154] Jin F, Zhou Z, Enomoto H, Moriya T, Higashijima H. Conversion mechanism of cellulosic biomass to lactic acid in subcritical water and acid-base catalytic effect of subcritical water. Chemistry Letters 2004;33:126-7.

[155] Garrote G, Eugenio ME, Díaz MJ, Ariza J, López F. Hydrothermal and pulp processing of Eucalyptus. Bioresource Technology 2003;88:61-8.

[156] Alfaro A, López F, Pérez A, García JC, Rodríguez A. Integral valorization of tagasaste (Chamaecytisus proliferus) under hydrothermal and pulp processing. Bioresource Technology 2010;101:7635-40.

[157] Caparrós S, Díaz MJ, Ariza J, López F, Jiménez L. New perspectives for Paulownia fortune L. valorization of the autohydrolysis and pulping processes. Bioresource Technology 2008;99:741-9.

[158] Kayserilioglu BS, Bakir U, Yilmaz L, Akkas N. Use of Xylan, an agricultural by-product, in wheat gluten based biodegradable films: mechanical, solubility and water vapor transfer rate properties. Bioresource Technology 2003;87:239-46.

[159] Sun XF, Sun R, Fowler P, Baird MS. Extraction and characterization of original lignin and hemicellulose from wheat straw. Journal of Agricultural and Food Chemistry 2005;53:860-70.

[160] Vegas R, Kabel M, Schols HA, Alonso JL, Parajó JC. Hydrothermal processing of rice husks: effects of severity on products distribution. Journal of Chemical Technology \& Biotechnology 2008;83:965-72.

[161] Carvalheiro F, Silva-Fernandes T, Duarte LC, Gírio FM. Wheat straw autohydrolysis: process optimization and products characterization. Applied Biochemistry and Biotechnology 2009;153:84-93.

[162] Parajó JC, Garrote G, Cruz JM, Dominguez H. Production of xylooligosaccharides by autohydrolysis of lignocellulosic materials. Trends in Food Science \& Technology 2004; 15:115-20.

[163] Gullón P, Moura P, Esteves MP, Gírio FM, Domínguez H, Parajó JC. Assessment on the fermentability of xylooligosaccharides from rice husks by probiotic bacteria. Journal of Agricultural and Food Chemistry 2008;56:7482-7.

[164] Carvalheiro F, Esteves MP, Parajó JC, Pereira H, Gírio FM. Production of oligosaccharides by autohydrolysis of brewery's spent grain. Bioresource Technology 2004;91:93-100.

[165] Kabel MA, Carvalheiro F, Garrote G, Avgerinos E, Koukios E, Parajó JC, et al. Hydrothermally treated xylan rich by-products yield different classes of xylo-oligosaccharides. Carbohydrate Polymers 2002;50:47-56.

[166] Gullón P, Pereiro G, Alonso JL, Parajó JC. Aqueous pretreatment of agricultural wastes: characterization of soluble reaction products. Bioresource Technology 2009;100:5840-5.

[167] Nabarlatz D, Torras C, Garcia-Valls R, Montané D. Purification of xylooligosaccharides from almond shells by ultra-filtration. Separation and Purification Technology 2007;53:235-43.

[168] Garrote G, Yáñez R, Alonso JL, Parajó JC. Coproduction of oligosaccharides and glucose from corncobs by hydrothermal processing and enzymatic hydrolysis. Industrial \& Engineering Chemistry Research 2008;47:1336-45.

[169] Montané D, Nabarlatz D, Martorell A Torné-Fernández V, Fierro V. Removal of lignin and associated impurities from xylo-oligosaccharides by activated carbon adsorption. Industrial \& Engineering Chemistry Research 2006;45:2294-302.

[170] Vegas R, Moure A, Domínguez H, Parajó JC, Álvarez JR, Luque S. Purification of oligosaccharides from rice husk autohydrolysis liquors by ultra-and nano-filtration. Desalination 2006;199:541-3.

[171] Garrote G, Parajó JC. Non-isothermal autohydrolysis of Eucalyptus wood. Wood Science and Technology 2002;36:111-23.

[172] Garrote G, Dominguez H, Parajó JC. Study on the deacetylation of hemicelluloses during the hydrothermal processing of Eucalyptus wood. Holz Roh Werkst 2001;59:53-9.

[173] Rivas B, Domínguez JM, Domínguez H, Parajó JC. Bioconversion of posthydrolysed autohydrolysis liquors: an alternative for xylitol production from corn cobs. Enzyme and Microbial Technology 2002;31:431-8.

[174] Duarte LC, Carvalheiro F, Lopes S, Marques S, Parajó JC, Gírio FM. Comparison of two posthydrolysis processes of brewery's spent grain autohydrolysis liquor to produce a pentose-containing culture medium. Applied Biochemistry and Biotechnology 2004;113-116:1041-58.
[175] Garrote G, Domínguez H, Parajó JC. Manufacture of xylose-based fermentation media from corncobs by posthydrolysis of autohydrolysis liquors. Applied Biochemistry and Biotechnology 2001;95:195-207.

[176] Garrote G, Domínguez H, Parajó JC. Generation of xylose solutions from Eucalyptus globulus wood by autohydrolysis-posthydrolysis processes: posthydrolysis kinetics. Bioresource Technology 2001;79:155-64.

[177] Vázquez MJ, Alonso JL, Domínguez H, Parajó JC. Production of xylosecontaining fermentation media by enzymatic pos-hydrolysis of oligomers produced by corn cob autohydrolysis. World Journal of Microbiology and Biotechnology 2001;17:817-22.

[178] Akpinar O, Erdogan K, Bostanci S. Production of xylooligosaccharides by controlled acid hydrolysis of lignocellulosic materials. Carbohydrate Research 2009;344:660-6.

[179] Glasser WG, Jain RK, Sjosted MA, inventors; The center for innovative technology. Thermoplastic pentose-rich polysaccharides from biomass. United States patent US 5,430,142. Jul. 41995

[180] Lindblad MS, Ranucci E, Albertsson AC. Biodegradable polymer from renewable sources. New hemicellulose-based hydrogels. Macromolecular Rapid Communications 2001;22:962-7.

[181] Vila C, Campos AR, Cristovão C, Cunha AM, Santos V, Parajó JC. Sustainable biocomposites based on autohydrolysis of lignocellulosic substrates. Composites Science and Technology 2008;68:944-52.

[182] González D, Campos AR, Cunha AM, Santos V, Parajó JC. Manufacture of fibrous reinforcements for biodegradable biocomposites from Citysus scoparius. Journal of Chemical Technology \& Biotechnology 2011;86:575-83.

[183] Garrote G, Cruz JM, Moure A, Domínguez H, Parajó JC. Antioxidant activity of byproducts from the hydrolytic processing of selected lignocellulosic materials. Trends in Food Science \& Technology 2004;15:191-200.

[184] Buranov AU, Mazza G. Lignin in straw of herbaceous crops. Industrial Crops and Products 2008;28:237-59.

[185] Pandey MP, Kim CS. Lignin depolymerization and conversion: a review of thermal methods. Chemical Engineering \& Technology 2011;34:29-41.

[186] Fang Z, Sato T, Smith Jr. RL, Inomata H, Arai K, Kozinski JA. Reaction chemistry and phase behavior of lignin in high-temperature and supercritical water. Bioresource Technology 2008;99:3424-30.

[187] Zhang B, Huang HJ, Ramaswamy S. Reaction kinetics of the hydrothermal treatment of lignin. Applied Biochemistry and Biotechnology 2008;147:119-31.

[188] Chi C, Zhang Z, Chang HM, Jameel H. Determination of furfural and hydroxymethylfurfural formed from biomass under acidic conditions. Journal of Wood Chemistry and Technology 2009;29:265-76.

[189] Schmidt JA. Electronic spectroscopy of lignins. In: Heitner C, Dimmel D, Schmidt JA, editors. Lignin and lignans: advances in chemistry. Florida: CRC press; 2010. p. 49-102.

[190] Esteves B, Graça J, Helena P. Extractive composition and summative chemical analysis of thermally treated eucalypt wood. Holzforschung 2008:62:344-51.

[191] Marchessault RH, Coulombe S, Morikawa H. Characterization of aspen exploded wood lignin. Canadian Journal of Chemistry 1982;60:2372-82.

[192] Conde E, Moure A, Domínguez H, Parajó JC. Production of antioxidants by non-isothermal autohydrolysis of lignocellulose wastes. LWT - Food Science and Technology 2011;44:436-42.

[193] Conde E, Moure A, Domínguez H, Parajó JC. Fractionation of antioxidants from autohydrolysis of barley husks. Journal of Agricultural and Food Chemistry 2008;56:10651-9.

[194] Garrote G, Domínguez H, Parajó JC. Production of substituted oligosaccharides by hydrolytic processing of barley husks. Industrial \& Engineering Chemistry Research 2004;43:1608-14.

195] Castro E, Conde E, Moure A, Falqué E, Cara C, Ruiz E, et al. Antioxidant Activity of liquors from steam explosion of Olea europea wood. Wood Science and Technology 42:579-592.

[196] Conde E, Cara C, Moure A, Ruiz E, Castro E, Domínguez H. Antioxidant activity of the phenolic compounds released by hydrothermal treatments of olive tree pruning. Food Chemistry 2009;114:806-12.

[197] Tsubaki S, Sakamoto M, Azuma J. Microwave-assisted extraction of phenolic compounds from tea residues under autohydrolytic conditions. Food Chemistry 2010;123:1255-8.

[198] Conde E, Gullón P, Moure A, Domínguez H, Parajó JC. Fractionation of industrial solids containing barley husks in aqueous media. Food and Bioproducts Processing 2009;87:208-14.

[199] Pourali O, Asghari FS, Yoshida H. Production of phenolic compounds from rice bran biomass under subcritical water conditions. Chemical Engineering Journal 2010;160:259-66.

[200] Tripoli E, Giammanco M, Tabacchi G, Majo DD, Giammanco S, Guardia ML. The phenolic compounds of olive oil: structure, biological activity and beneficial effects on human health. Nutrition Research Reviews 2005;18: 98-112.

[201] Kim YJ. Antimelanogenic and antioxidant properties of gallic acid. Biological \& Pharmaceutical Bulletin 2007;30:1052-5.

[202] Jung HJ, Song YS, Lim CJ, Park EH. Anti-angiogenic, anti-inflammatory and anti-nociceptive activities of vanillyl alcohol. Archives of Pharmacal Research 2008;31:1275-9.

[203] Serzer WN. Lignin-derived oak phenolics: a theoretical examination of additional potential health benefits of red wine. Journal of Molecular Modeling 2011;17:1841-5. 
[204] Tsubaki S, Iida H, Sakamoto M, Azuma JI. Microwave heating of tea residue yields polysaccharides, polyphenols and plant biopolyester. Journal of Agricultural and Food Chemistry 2008;56:11293-9.

[205] Akpinar O, Gunay K, Yilmaz Y, Levent O, Bostanci S. Enzymatic Processing and antioxidant activity of agricultural waste autohydrolysis liquors. BioResources 2010;5:699-711.

[206] Tsubaki S, Ozaki Y, Azuma J. Microwave-assisted autohydrolysis of Prunus mume stone for extraction of polysaccharides and phenolic compounds. Journal of Food Science 2010;75:152-9.

[207] Li J, Gellerstedt G. Improved lignin properties and reactivity by modifications in the autohydrolysis process of aspen wood. Industrial Crops and Products 2008;27:175-81.

[208] Hongzhang C, Liying L. Unpolluted fractionation of wheat straw by steam explosion and ethanol extraction. Bioresource Technology 2007;98:666-76.

[209] Anastasakis K, Ross AB, Jones JM. Pyrolysis behaviour of the main carbohydrates of brown macro-algae. Fuel 2011;90:598-607.

[210] Aresta M, Dibenedetto A, Barberio G. Utilization of macro-algae for enhanced $\mathrm{CO}_{2}$ fixation and biofuels production: development of computing software for an LCA study. Fuel Processing Technology 2005;86:1679-93.

[211] Ross AB, Jones JM, Kubacki ML, Bridgeman T. Classification of macroalgae as fuel and its thermochemical behaviour. Bioresource Technology 2008;99: 6494-504.

[212] Anastasakis K, Ross AB. Hydrothermal liquefaction of the brown macro-alg Laminaria Saccharina: effect of reaction conditions on product distribution and composition. Bioresource Technology 2011;102:4876-83.

[213] Iersel SV, Flammini A. Algae-base biofuels: applications and co-products. FAO. In: environmental and natural resources management working. Rome, Italy; 2010:117.

[214] John RP, Anisha GS, Nampoothiri KM, Pandey A. Micro and macroalgal biomass: a renewable source for bioethanol. Bioresource Technology 2011;102:186-93.

[215] Matsui T, Koike Y. Methane fermentation of a mixture of seaweed and milk at a pilot-scale plant. Journal of Bioscience and Bioengineering 2010;110 558-63.

[216] Horn SJ, Aasen IM, Østgaard K. Ethanol production from seaweed extract Journal of Industrial Microbiology and Biotechnology 2000;25:249-54.

[217] Adams JM, Gallagher JA, Donnison IS. Fermentation study on Saccharin latissima for bioethanol production considering variable pre-treatments. Journal of Applied Phycology 2009;21:569-74.

[218] Ji-Hyeon Y, Lee S, Choi WY, Kang DH, Lee H, Jung K. Repeated-batch operation of surface-aerated fermentor for bioethanol production from the hydrolysate of seaweed sargassum sagamianum. Journal of Industria Microbiology and Biotechnology 2011;21:323-31.

[219] Lee S, Lee J. The isolation and characterization of simultaneous saccharification and fermentation microorganisms for Laminaria japonica utilization. Bioresource Technology 2011;102:5962-7.

[220] Wang S, Jiang XM, Han XX, Liu JG. Combustion characteristics of seaweed biomass. 1. Combustion characteristics of Enteromorpha clathrata and Sargassum natans. Energ Fuels 2009;23:5173-8.

[221] Ross AB, Anastasakis K, Kubacki M, Jones JM. Investigation of the pyrolysis behaviour of brown algae before and after pre-treatment using PY-GC/MS and TGA. Journal of Analytical and Applied Pyrolysis 2009;85:3-10.

[222] Aida TM, Yamagata T, Abe C, Kawanami H, Watanabe M, Smith Jr. RL. Production of organic acids from alginate in high temperature water. The Journal of Supercritical Fluids 2012;65:39-44.

[223] Schumacher M, Yanik J, Sinag A, Kruse A. Hydrothermal conversion of seaweeds in a batch autoclave. The Journal of Supercritical Fluids 2011;58:131-5

[224] Ross AB, Biller P, Kubacki ML, Li H, Lea-Langton A, Jones JM. Hydrothermal processing of microalgae using alkali and organic acids. Fuel 2010;89:2234-43.

[225] Zhou D, Zhang L, Zhang S, Fu H, Chen J. Hydrothermal liquefaction of macroalgae Enteromorpha prolifera to bio-oil. Energy \& Fuels 2010;24: 4054-61.

[226] Biller P, Ross AB. Potential yields and properties of oil from the hydrothermal liquefaction of microalgae with different biochemical content. Bioresource Technology 2011;102:215-25.

[227] Herrero M, Cifuentes A, Ibañez E. Sub- and supercritical fluid extraction of functional ingredients from different natural sources: plants, food-byproducts, algae and microalgae. A review. Food Chemistry 2006;98:136-48.

[228] Aresta M, Dibenedetto A, Carone M, Colonna T, Fragale C. Production of biodiesel from macroalgae by supercritical $\mathrm{CO}_{2}$ extraction and thermochemical liquefaction. Environmental Chemistry Letters 2005;3:136-9.

[229] Kim NJ, Li H, Jung K, Chang HN, Lee PC. Ethanol production from marine algal hydrolysates using Escherichia coli K011. Bioresource Technology 2011:102:7466-9.

[230] Srogi KA. Review: application of microwave techniques for environmental analytical chemistry. Analytical Letters 2006;39:1261-88.

[231] Rodriguez-Jasso RM, Mussatto SI, Pastrana L, Aguilar CN, Teixeira JA Microwave-assisted extraction of sulfated polysaccharides (fucoidan) from brown seaweed. Carbohydrate Polymers 2011:1137-44.

[232] Zvyagintseva TN, Shevchenko NM, Nazarova IV, Scobun AS, Luk'yanov PA, Elyakova LA. Inhibition of complement activation by water-soluble polysaccharides of some far-eastern brown seaweeds. Comparative
Biochemistry and Physiology Part C: Toxicology \& Pharmacology 2000;126: 209-15.

[233] Chen X, Liu Q, Xin Jiang, Zeng Z. Microwave-assisted extraction of polysaccharides from Solanum nigrum. Journal of Central South University of Technology 2005;12:556-60.

[234] Navarro DA, Stortz CA. Microwave-assisted alkaline modification of red seaweed galactans. Carbohydrate Polymers 2005;62:187-91.

[235] Yang C, Chung D, You S. Determination of physicochemical properties of sulphated fucans from sporophyll of Undaria pinnatifida using light scattering technique. Food Chemistry 2008;111:503-7.

[236] Uy SF, Easteal AJ, Farid MM, Keam RB, Conner GT. Seaweed processing using industrial single-mode cavity microwave heating: a preliminary investigation. Carbohydrate Research 2005;340:1357-64.

[237] González-López N, Moure A, Domínguez H. Hydrothermal fractionation of Sargassum muticum biomass. Journal of Applied Phycology 2012;24: 1569-78.

[238] Anastyuk SD, Shevchenko NM, Dmitrenok PS, Zvyagintseva TN. Structural similarities of fucoidans from brown algae Silvetia babingtonii and Fucus evanescens, determined by tandem MALDI-TOF mass spectrometry. Carbohydrate Research 2012;358:78-81.

[239] Anastyuk SD, Shevchenko NM, Ermakova SP, Vishchuk OS, Nazarenko EL, Dmitrenok PS, et al. Anticancer activity in vitro of a fucoidan from the brown alga Fucus evanescens and its low-molecular fragments, structurally characterized by tandem mass-spectrometry. Carbohydrate Polymers 2012;87:186-94.

[240] Rodríguez-Jasso RM, Mussato SI, Pastrana L, Aguilar CN, Teixeira JA Extraction of sulfated polysaccharides by autohydrolysis of brown seaweed Fucus vesiculosus. Journal of Applied Phycology (In press); http://dx.doi.org/10. 1007/s10811-012-9834-0.

[241] Dragone G, Fernandes B, Vicente AA, Teixeira JA. Third generation biofuels from microalgae. In: Mendez-Vilas A, editor. Current research, technology and education topics in applied microbiology and microbial biotechnology (Microbiology Book Series 2). Badajoz: Formatex; 2010. p. 1355-66.

[242] Lardon L, He'lias A, Sialve B, Steyer J-P, Bernard O. Life-cycle assessment of biodiesel production from microalgae. Environmental Science \& Technology 2009;43:6475-81.

[243] Patil V, Tran K-Q Giselrød HR. Towards Sustainable Production of Biofuels from Microalgae. International Journal of Molecular Sciences 2008;9:1188-95.

[244] Shuping Z, Yulong W, Mingde Y, Kaleem I, Chun L, Tong J. Production and characterization of bio-oil from hydrothermal liquefaction of microalgae Dunaliella tertiolecta cake. Energy 2010;35:5406-11.

[245] Biller P, Riley R, Ross AB. Catalytic hydrothermal processing of microalgae: decomposition and upgrading of lipids. Bioresource Technology 2011;102:4841-8.

[246] Heilmann SM, Davis HT, Jader LR, Lefebvre PA, Sadowsky MJ, Schendel FJ, et al. Hydrothermal carbonization of microalgae. Biomass \& Bioenergy 2010;34:875-82.

[247] Dote Y, Sawayama S, Inoue S, Minowa T, Yokoyama S-Y. Recovery of liquid fuel from hydrocarbon-rich microalgae by thermochemical liquefaction. Fuel 1994;73:1855-87.

[248] Sawayama S, Inoue S, Dote Y, Yokoyama S-Y. $\mathrm{CO}_{2}$ fixation and oil production through microalga. Energy Conversion and Management 1995;36:729-31.

[249] Banerjee A, Sharma R, Chisti Y, Banerjee UC. Botryococcus braunii: a renewable source of hydrocarbons and other chemicals. Critical Reviews in Biotechnology 2002:22:245-70.

[250] Minowa T, Yokoyama S-y, Kishimoto M, Okakura T. Oil production from algal cells of Dunaliella tertiolecta by direct thermochemical liquefaction. Fuel 1995;74:1735-8.

[251] Matsui T-o, Nishihara A, Ueda C, Ohtsuki M, Ikenaga N-o, Suzuki T. Liquefaction of micro-algae with iron catalyst. Fuel 1997;76:1043-8.

[252] Yang YF, Feng CP, Inamori Y, Maekawa T. Analysis of energy conversion characteristics in liquefaction of algae. Resources, Conservation and Recycling 2004;43:21-33.

[253] Brown TM, Duan P, Savage PE. Hydrothermal Liquefaction and Gasification of Nannochloropsis sp. Energy \& Fuels 2010;24:3639-46.

[254] Alba LG, Torri C, Samori C, Spek JVD, Fabbri D, Kersten RA, et al. Hydrothermal treatment (HTT) of microalgae: evaluation of the process as conversion method in an algae biorefinery concept. Energy \& Fuels 2011;26: 642-57.

[255] Duan P, Savage PE. Hydrothermal liquefaction of a microalga with heterogeneous catalysts. Industrial \& Engineering Chemistry Research 2010;50:52-61.

[256] Jena U, Vaidyanathan N, Chinnasamy S, Das KC. Evaluation of microalgae cultivation using recovered aqueous co-product from thermochemical liquefaction of algal biomass. Bioresource Technology 2011;102:3380-7.

[257] Yeh TM, Dickinson JG, Frank A, Linic S, ThompsonJr. LT. Savage PE Hydrothermal catalytic production of fuels and chemicals from aquatic biomass. Journal of Chemical Technology \& Biotechnology 2013;88:13-24.

[258] Sawayama S, Minowa T, Yokoyama SY. Possibility of renewable energy production and $\mathrm{CO}_{2}$ mitigation by thermochemical liquefaction of microalgae. Biomass \& Bioenergy 1999;17:33-9.

[259] Shen Z, Zhou J, Zhou X, Zhang Y. The production of acetic acid from microalgae under hydrothermal conditions. Applied Energy 2011;88: 3444-7. 